\title{
Harmful effects of metal(loid) oxide nanoparticles
}

\author{
Eduardo V. Soares ${ }^{1,2}$ (D) Helena M. V. M. Soares $^{3}$ (D) \\ Received: 1 October 2020 / Revised: 4 January 2021 / Accepted: 16 January 2021 / Published online: 1 February 2021 \\ (C) The Author(s), under exclusive licence to Springer-Verlag GmbH, DE part of Springer Nature 2021
}

\begin{abstract}
The incorporation of nanomaterials (NMs), including metal(loid) oxide (MOx) nanoparticles (NPs), in the most diversified consumer products, has grown enormously in recent decades. Consequently, the contact between humans and these materials increased, as well as their presence in the environment. This fact has raised concerns and uncertainties about the possible risks of NMs to human health and the adverse effects on the environment. These concerns underline the need and importance of assessing its nanosecurity. The present review focuses on the main mechanisms underlying the MOx NPs toxicity, illustrated with different biological models: release of toxic ions, cellular uptake of NPs, oxidative stress, shading effect on photosynthetic microorganisms, physical restrain and damage of cell wall. Additionally, the biological models used to evaluate the potential hazardous of nanomaterials are briefly presented, with particular emphasis on the yeast Saccharomyces cerevisiae, as an alternative model in nanotoxicology. An overview containing recent scientific advances on cellular responses (toxic symptoms exhibited by yeasts) resulting from the interaction with MOx NPs (inhibition of cell proliferation, cell wall damage, alteration of function and morphology of organelles, presence of oxidative stress bio-indicators, gene expression changes, genotoxicity and cell dead) is critically presented. The elucidation of the toxic modes of action of MOx NPs in yeast cells can be very useful in providing additional clues about the impact of NPs on the physiology and metabolism of the eukaryotic cell. Current and future trends of MOx NPs toxicity, regarding their possible impacts on the environment and human health, are discussed.
\end{abstract}

\section{Key points}

- The potential hazardous effects of MOx NPs are critically reviewed.

- An overview of the main mechanisms associated with MOx NPs toxicity is presented.

- Scientific advances about yeast cell responses to MOx NPs are updated and discussed.

Keywords Aquatic organisms $\cdot$ Hazard/risk assessment $\cdot$ Metal(loid) oxide nanoparticles $\cdot$ Nanosafety $\cdot$ Toxic modes of action Yeast

Eduardo V. Soares

evs@isep.ipp.pt

1 Bioengineering Laboratory-CIETI, ISEP-School of Engineering, Polytechnic Institute of Porto, rua Dr António Bernardino de Almeida, 431, 4249-015 Porto, Portugal

2 CEB-Centre of Biological Engineering, University of Minho, Campus de Gualtar, 4710-057 Braga, Portugal

3 REQUIMTE/LAQV, Departamento de Engenharia Química, Faculdade de Engenharia, Universidade do Porto, rua Dr Roberto Frias, s/n, 4200-465 Porto, Portugal

\section{Introduction}

Nanomaterials (NMs) are defined as "chemical substances or materials with particle sizes between 1 to $100 \mathrm{~nm}$ in at least one dimension" (ECHA 2020). Due to their nanometer size, they present huge surface-to-volume ratios, exhibiting unique physical and chemical properties (such as catalytic, optical, magnetic, electronic and mechanical) that are different from those of materials on a larger or "bulk" scale (Klaine et al. 2013). The exceptional properties exhibited by NMs have led to their incorporation in many products in various sectors such as agriculture, automotive, construction, cosmetics, electronics, environment, food, home appliance, medicine, petroleum and printing (NPD 2020). 
The rapid expansion of production and use of NMs inevitably raised concerns about their safety for human health and the environment. The physical form and the chemical reactivity that makes NMs distinctive also provide them the potential to interfere with biological processes and produce hazardous effects. Humans can be intentional (through nanomedicine or personal healthcare products) or unintentionally exposed to NMs (released from food packaging); additionally, occupational exposure (as consequence of industrial processes) should also be considered (Lombi et al. 2019; Klaper 2020). Examples of intentional application of NMs in the environment include their use in environmental remediation (Guerra et al. 2018; Qian et al. 2020) or in agricultural practices (Servin et al. 2015; Usman et al. 2020). Unintentionally release of NMs in the environment includes the following: (i) the release due to the life cycle of products incorporating NPs, such as paints, cosmetics, sunscreens (Sun et al. 2016; Wu et al. 2020); and, (ii) accidental spills or industrial liquid effluents, such as those emitted by textile industries during the washing of nanotextiles (Yetisen et al. 2016). It was estimated that of the global NMs produced, 63-91\% reach landfills, 8-28\% are released into soils, $0.4-0.7 \%$ in natural water bodies, and $0.1-1.5 \%$ are released into the atmosphere (Keller et al. 2013).

NMs can be divided into five categories: carbon-based (single and multi-walled carbon nanotubes, graphene and fullerenes); metal-based (metal(loid) oxides; zerovalent metals such as iron, silver and gold); dendrimers (hyperbranched polymers, dendrigraft polymers and dendrons); semiconductor nanocrystals, known as quantum dots; and composites (constituted by two different NMs or NMs combined with larger, bulk-type materials; and NMs combined with synthetic polymers or resins) (EPA 2017).

Among NMs, metal(loid) oxide (MOx) nanoparticles (NPs) have received considerable attention largely due to their variety of uses namely in optics and electronics, healthcare, construction, automotive and personal care products (Laurent et al. 2018), and it will be the subject of the present review. The market for MOx NPs is expected to growth at a compound annual growth over $7 \%$ globally during the period of 2020-2025. However the current framework of uncertainty arising from the COVID-19 pandemic it may hinder the growth of this market sector (Mordor Intelegence 2020).

In the last five years, several review papers have been published about NMs, NPs or more specifically on MOx NPs. Some reviews refer more broadly to NMs, namely about their behaviour, fate, bioavailability and effects on the environment (Pulido-Reyes et al. 2017; Lead et al. 2018; Spurgeon et al. 2020; Zhao et al. 2020) or the toxicity mechanisms associated with NMs over algal cells (Chen et al. 2019). Within NMs, reviews on NPs, namely about the influence of their physicochemical properties on ecotoxicology, in terrestrial and aquatic systems (Bundschuh et al. 2018; Nguyen et al. 2020; Roma et al. 2020), the effects on freshwater organisms (Deniel et al.
2019), genotoxicity (Mortezaee et al. 2019) or the mechanisms associated with cell dead by necrosis, apoptosis and autophagy (Mohammadinejad et al. 2019; Paunovic et al. 2020) have been published. A more specific review about the toxic effects of $\mathrm{NiO}$ in aquatic organisms (Meyer et al. 2020) was recently published.

The present work summarises the main mechanisms underlying MOx NPs toxicity. The biological models used to assess nanotoxicity are briefly presented, with particular emphasis on the yeast Saccharomyces cerevisiae as a valuable and alternative model in nanotoxicology. An updated overview of yeast cell responses to stress induced by MOx NPs is critically reviewed. Finally, current and future trends in the assessment of MOx NPs toxicity, regarding their possible impact on the environment and human health, are discussed.

\section{Biological models used in nanotoxicology}

\section{Brief overview of the models used in nanotoxicity assessment}

An array of biological models have been used in ecotoxicity studies, which include (in parentheses it can be found typical examples employed): bacteria (Escherichia coli and Vibrio fischeri), yeasts (S. cerevisiae), microalgae (Pseudokirchneriella subcapitata and Chlorella vulgaris), protozoa (Tetrahymena thermophila), rotifers (Brachionus plicatilis), crustaceans (Daphnia magna), annelids (Eisenia fetida), nematodes (Caenorhabditis elegans), cnidarians (Hydra attenuata), molluscs (Potamopyrgus antipodarum), echinoderms (Lytechinus pictus), amphibians (Xenopus laevis) and fishes (Danio rerio) (Juganson et al. 2015; Minetto et al. 2016; Libralato et al. 2017).

Although animal testing is still the predominant model use for the risk assessment of chemicals (Hartung and Rovida 2009), due to the pressure from public opinion and legal demand, supported by ethical reasons, the replacement of animals for cheaper and more humanrelevant alternatives have been proposed based on the use of cell lines. Thus, different mammalian cell lines have been used in toxicity assays with MOx NPs $\left(\mathrm{Al}_{2} \mathrm{O}_{3}, \mathrm{CuO}\right.$, $\mathrm{NiO}, \mathrm{TiO}_{2}$ and $\mathrm{ZnO}$ ), comprising models of different human systems, such as respiratory, digestive, renal, immune and skin (Ivask et al. 2014; Naseer et al. 2018; Czyzowska and Barbasz 2020).

\section{The yeast S. cerevisiae as an important tool in nanotoxicology}

S. cerevisiae is the most commonly used yeast in industrial applications, receiving the status of Generally Recognized As Safe (GRAS) microorganism by the United States Food and Drug Administration (FDA 2018). This yeast is easy to 
manipulate and cultivate, does not require expensive ingredients in the formulation of the culture media and presents a short generation time. It was the first eukaryotic organism with the genome completely sequenced (Goffeau et al. 1996).

The yeast $S$. cerevisiae presents a cellular structure and organization related to animal cells. About $30 \%$ of genes associated with human diseases have a yeast orthologue (Foury 1997), which makes this yeast an attractive model organism to study diseases in humans. Mitochondrial respiration can be manipulated by the loss of mitochondrial DNA or by changing the growth conditions, making this yeast an appropriate model for elucidating the role of mitochondria in ROS generation, as well as mitochondrial diseases associated with oxidative phosphorylation (Malina et al. 2018); this information can be readily transported to higher eukaryotes via the Gene Ontology (Howe et al. 2018).

This yeast features a set of important tools that include the complete gene deletion collection (Giaever and Nislow 2014) and the possibility of achieving high-throughput data, such as obtained from transcriptomics, proteomics and metabolomics analysis (Braconi et al. 2016). The use of yeasts in the assessment of toxicity of environmental pollutants (including NMs) does not raise ethical issues and is well suited in a first toxicity screening, because reduces costs and toxic wastes and replaces/limits the use of animal models (dos Santos and Sa-Correia 2015).

However, this model also has limitations. The unicellular nature of this organism does not make possible to provide specific toxicological data about tissues or organs. In addition, it presents a cell wall (in contrast to animal cells), which can act as a barrier to toxicants, many efflux pumps and detoxification mechanisms, which can be the cause of the greater tolerance of yeasts to toxics, compared with eukaryotic cells of higher organisms (dos Santos et al. 2012; Braconi et al. 2016).

\section{Global mechanisms underlying to MOx NPs toxicity}

MOx NPs can present a toxic effect by several mechanisms, in some cases even by more than one. The main mechanisms are summarised below and depicted in Fig. 1.

\section{NPs solubilisation: release of toxic ions}

MOx NPs dissolution, to a greater or lesser extent, is a common transformation process, which is dependent on their physico-chemical properties (chemical composition and size), presence of stabilizing agents and chemical composition of the medium, namely, $\mathrm{pH}$, ionic strength (IS), presence of anions (phosphate and sulphate) and natural organic matter (Quigg et al. 2013; Amde et al. 2017).

Once in solution, the ions diffuse in the medium and reach the cells, where they produce a deleterious effect after intracellular accumulation (Fig. 1A). Metal ions, as charged chemical species, do not diffuse freely across the plasma membrane. Thus, different membrane transport proteins (pumps and channels) are involved in their influx (Argueello et al. 2012).

In certain MOx NPs, the ions dissolved seem to be the major factor in their ecotoxicity. This is the case of the toxic impact of ZnO NPs over bacteria (Heinlaan et al. 2008; Li et al. 2011; Wang et al. 2016), yeasts (Kasemets et al. 2009; Bayat et al. 2014), crustaceans (Heinlaan et al. 2008; Wiench et al. 2009; Vimercati et al. 2020), microalgae (Franklin et al. 2007; Miller et al. 2010; Lee and An 2013; Aravantinou et al. 2015; Schiavo et al. 2016) or mammalian cell lines (Brunner et al. 2006; Zhang et al. 2012), which is totally or mainly caused by solubilized $\mathrm{Zn}$ ions. A Multi-omics approach (transcriptomics, metabolomics and lipidomics) confirmed that metal ions mediated the main toxicological pathways of ZnO NPs in lung epithelial A549 cells (Dekkers et al. 2018). In the same line, $\mathrm{CuO}$ NPs toxicity over bacteria (Bondarenko et al. 2012), yeasts (Kasemets et al. 2009; Kasemets et al. 2013; Bayat et al. 2014; Bao et al. 2015), green algae (Aruoja et al. 2009; von Moos et al. 2015), crustaceans (Heinlaan et al. 2008; Jo et al. 2012) or human cell lines (Cohen et al. 2013; He et al. 2020) was partially or completely explained by dissolved $\mathrm{Cu}$ ions. The toxicity of $\mathrm{NiO}$ and $\mathrm{SnO}_{2}$ over P. subcapitata (Sousa et al. 2018b; Sousa et al. 2019b) or $\mathrm{Mn}_{3} \mathrm{O}_{4}$ and $\mathrm{Y}_{3} \mathrm{O}_{3}$ over $S$. cerevisiae (Moriyama et al. 2019; Sousa et al. 2019a) can also be mainly attributed to the respective ions leached from the NPs.

\section{NPs passage through wall pores versus release of metal ions on NPs-cell surface interface}

The cell wall, present in plants, in most bacteria, yeasts and in many microalgae, is the primary site of interaction and the first barrier to the passage of NPs from the extracellular medium to the cytoplasm. This cellular structure is absent in animal cells and protozoa. The second barrier is the plasma membrane, common to all cells. Chemical composition and architecture of the cell wall vary according to the organism, being their thickness an important factor in the determination of the NPs internalisation (Chen et al. 2019). This cell structure is generally seen as a porous matrix. For instance, the yeast $S$. cerevisiae presents cell wall pores of $200 \mathrm{~nm}$, which can be enlarged up to $400 \mathrm{~nm}$ under stress conditions (Pereira and Geibel 1999). Cell wall pore diameter of 7-8 $\mathrm{nm}$ in marine macro algae (ZemkeWhite et al. 2000) and pore channels with an average diameter of 20-200 $\mathrm{nm}$ in unicellular green microalgae were also described (Anissimova and Staer 2018). It is conceivable that, in organisms with cell wall, NPs and NPs homoagglomerates smaller than wall pores can pass through this cellular structure and reach the plasma membrane (Fig. 1B, top). Conversely, NPs and NPs homoagglomerates larger than pore size are very unlikely to pass through cell wall (sieve effect). 


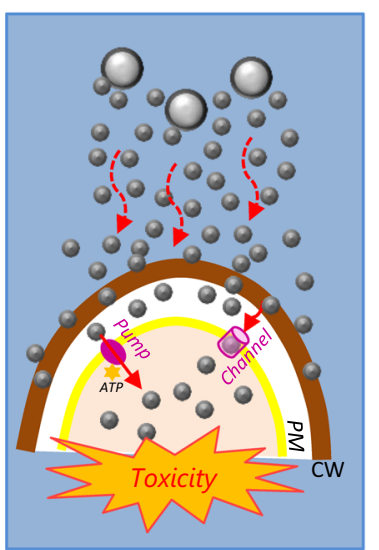

a
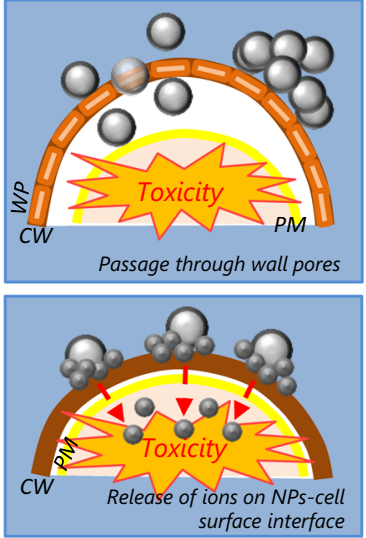

b

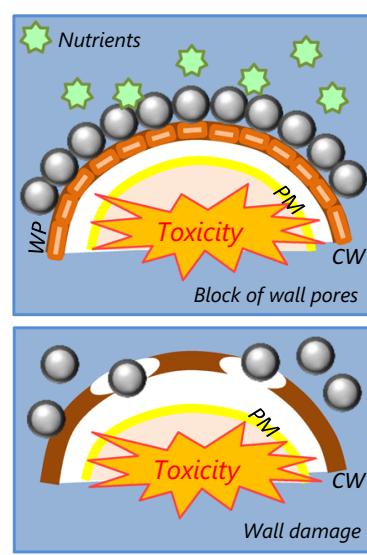

C

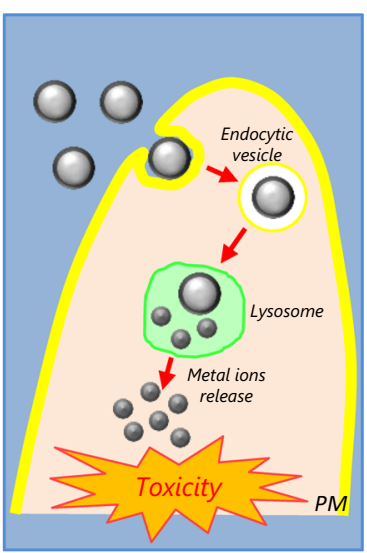

d

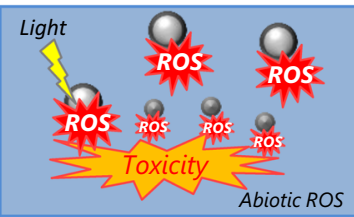

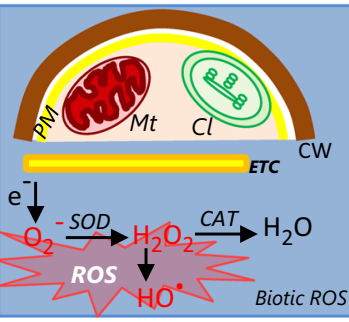

e

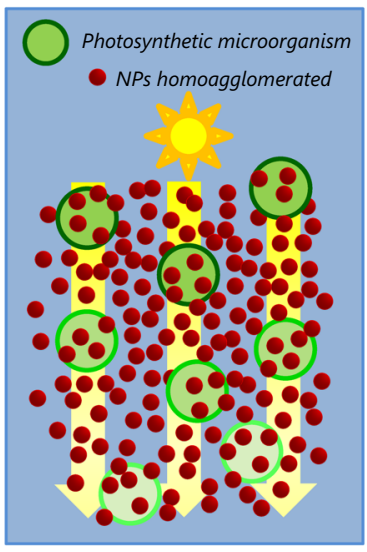

f

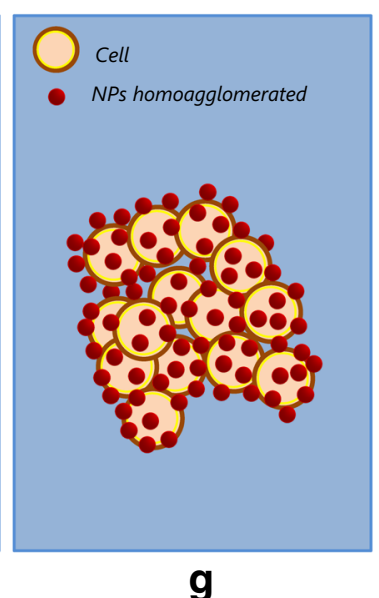

g

(on photosynthetic microorganisms): homoagglomeration of NPs. $\mathbf{g}$ Physical restraint: heteroagglomeration. CAT, catalase; $\mathrm{Cl}$, chloroplast; $\mathrm{CW}$, cell wall; ETC, electron transport chain; Mt, mitochondrion; NPs, nanoparticles; PM, plasma membrane; ROS, reactive oxygen species; SOD, superoxide dismutase

of metal ions on NPs-cell surface interface. $c$ Direct effect on the cell surface. d Cellular uptake of NPs. e Oxidative stress. f Shading effect

It was described that $\mathrm{CeO}_{2} \mathrm{NPs}$, coated with polyvinylpyrrolidone and presenting a size of $4-5 \mathrm{~nm}$, could cross the cell wall of the microalga Chlamydomonas reinhardtii being internalised into intracellular vesicles (Taylor et al. 2016). Using different microscopy techniques, the internalisation of $\mathrm{CuO}$ NPs in S. cerevisiae (Vasco et al. 2017) and in the C. reinhardtii (Yin et al. 2020) was also described. In the case of $C$. reinhardtii, $\mathrm{CuO}$ NPs were largely accumulated in the vacuoles (Yin et al. 2020). Conversely, it has been suggested that the internalisation of $\mathrm{CeO}_{2} \mathrm{NPs}$ (with a nominal size of $25 \mathrm{~nm}$ and presenting in solution agglomerates with an average size of $146 \mathrm{~nm}$ ) in C. reinhardtii was rather unlikely (nee Rohder et al. 2018). A similar conclusion was achieved in other studies with algae (Rodea-Palomares et al. 2011; Pulido-Reyes et al. 2015; Angel et al. 2015) and cyanobacterium (Rodea-Palomares et al. 2011). In this line, the examination by transmission electron microscopy (TEM)-energy-dispersive X-ray spectroscopy of yeast cells treated with $\mathrm{CuO}$ (Bao et al. 2015), NiO (Sousa et al. 2018a), or ZnO NPs
(Zhang et al. 2016) did not detect MOx NPs inside cells, suggesting that these NPs could not be taken by yeast cells. In resume, although examples of NPs internalisation in organisms with cell wall can be found in the literature, this is a debatable issue, especially the passage through the cell wall of agglomerated NPs.

However, different studies have attributed the toxic effects of MOx NPs to the NPs themselves rather than to the ions coming from them. This is the case of $\mathrm{NiO}$ (Sousa et al. 2018a), $\mathrm{SiO}_{2}$ (Sousa et al. 2019a) and $\mathrm{TiO}_{2}$ (Bayat et al. 2014) over yeasts as well as $\mathrm{Al}_{2} \mathrm{O}_{3}, \mathrm{CeO}_{2}$, $\mathrm{Fe}_{3} \mathrm{O}_{4}, \mathrm{Mn}_{3} \mathrm{O}_{4}$ and $\mathrm{WO}_{3}$ NPs on microalgae (Aruoja et al. 2015; Angel et al. 2015; Sousa et al. 2019b). In this context, MOx NPs can present a toxic effect by an indirect mechanism: particles adhere tightly to the cell wall of the microorganisms and enhance the release of metals at the NP-cell wall interface, leading to the activation of toxic responses (Fig. 1B, bottom). This indirect mechanism was suggested for to explain the antibacterial activity of 
$\mathrm{Fe}_{2} \mathrm{O}_{3}, \mathrm{Co}_{3} \mathrm{O}_{4}$ and NiO NPs (Wang et al. 2016) and the toxicity of $\mathrm{CuO}$ and $\mathrm{NiO}$ on yeasts (Kasemets et al. 2013; Bao et al. 2015; Sousa et al. 2018a) and $\mathrm{CeO}_{2}$ NPs on microalgae (Angel et al. 2015).

\section{Direct effect on the cell surface}

After contact and adsorption to the cell wall, NPs can clog the pores of the wall, limiting the exchange of chemical species (including nutrients) between the surrounding medium and the cell (Fig. 1C, top) or induce physical damage to the cell wall (Fig. 1C, bottom).

In agreement with the first possibility, it was described that C. reinhardtii incubated with $\mathrm{TiO}_{2}$ presented the cell surface coated with NPs, which can hinder the exchange of substances between the cell and the surrounding milieu (Chen et al. 2012). The functionalization and the type of functionalization of $\mathrm{CuO}$ and $\mathrm{ZnO}$ can influence the level of NPs adsorption to $S$. cerevisiae and C. reinhardtii cell wall and the respective anti-fungi and anti-algal activity (Halbus et al. 2019; Halbus et al. 2020).

The damage of the cell wall of algae and yeast cells incubated with ZnO NPs was described (Suman et al. 2015; Zhang et al. 2016; Babele et al. 2018). In the same way, it has been reported that $\mathrm{TiO}_{2} \mathrm{NPs}$ or $\mathrm{TiO}_{2} \mathrm{NPs}$ surface-bound humic acid adhered to algal cells (Chlorella spp., Karenia brevis, Nitzschia closterium and Skeletonema costatum) and could destroy the cell wall and enter the cells, inducing plasmolysis (Lin et al. 2012; Xia et al. 2015; Li et al. 2015). In the same mode, it has been proposed that the toxic effect of $\mathrm{CeO}_{2} \mathrm{NPs}$ on P. subcapitata can be mediated, mainly, by a physical effect due to a close adsorption of the NPs on the cell surface (Manier et al. 2013). This possibility is in line with other observations that describe that $\mathrm{CeO}_{2} \mathrm{NPs}$ are strongly adsorbed to Anabaena sp. and completely disrupt cyanobacterium cell wall and membrane (Rodea-Palomares et al. 2011). It is important to note that the adhesion of MOx NPs to the cell wall does not necessarily imply the triggering of a toxic effect. For instance, the attachment of $\mathrm{La}_{2} \mathrm{O}_{3}$ NPs to the cell wall did not produce morphological changes on Chlorella spp. (Balusamy et al. 2015).

\section{Cellular uptake of NPs}

After crossing the cell wall (in organisms with a cell wall and when such passage is possible), MOx NPs meet the cell membrane and two types of events can occur: damage of the membrane (due to physical disruption) (Chen et al. 2019) or passage through the membrane by endocytosis (Fig. 1D), a process well known in mammalian cells (Oh and Park 2014). Endocytosis was also suggested in microalgae and bacteria but their predominance and mechanisms are unknown (von Moos et al. 2014).
Once inside the cells, MOx NPs can undergo several alterations, such as redox transformations and complexation (Chen et al. 2019) or can be solubilized inside of acidic lysosomes (Fig. 1D) and exerts their toxicity by a Trojan horse-type mechanism (Oh and Park 2014). The intracellular dissolution mechanism affords the trafficking of toxic metal ions into the cells. Thus, $\mathrm{CuO}$ and $\mathrm{ZnO}$ NPs intracellular dissolution and release of $\mathrm{Cu}$ and $\mathrm{Zn}$ ions, respectively, were described in different mammalian (including human) cell lines (Xia et al. 2008; Cronholm et al. 2013; Condello et al. 2016; He et al. 2020).

\section{Oxidative stress}

Oxidative stress (OS) occurs when it is observed an imbalance between the generation of reactive species (RS) and the level of antioxidant defences, either enzymatic or non-enzymatic (Halliwell and Gutteridge 2015). MOx NPs themselves, or the metals released from them, can present a pro-oxidant potential, i.e. the capacity to generate the production of RS or hindering/consuming antioxidant defences ( $\mathrm{Nel}$ et al. 2006). Reactive oxygen species (ROS) production (such as superoxide radical $\left(\mathrm{O}_{2} \cdot{ }^{-}\right)$, hydroxyl radical $(\mathrm{HO} \cdot)$ and hydrogen peroxide $\left.\left(\mathrm{H}_{2} \mathrm{O}_{2}\right)\right)$ can occur under a cell free milieu, i.e. extracellularly (abiotic ROS) or via interaction of NPs (or the released ions) with biologicals systems (biotic ROS) (Fig. 1E).

ROS can be generated at the NP surface (Fig. 1E, top). The bioavailability and valence state of redox-active elements influences strongly the level of ROS generation by NPs. In a general way, the capacity of MOx NPs to generate ROS is dependent on their chemical composition, purity, (particle) size, shape and surface reactivity (von Moos and Slaveykova 2014). In certain NPs, such as $\mathrm{TiO}_{2}$, the ability to produce ROS may also require light or an ultraviolet source to excite the NPs surface (Xia et al. 2008; Guo et al. 2011) (Fig. 1E, top). ROS generation, in abiotic conditions, by $\mathrm{CeO}_{2}, \mathrm{Co}_{3} \mathrm{O}_{4}, \mathrm{CuO}$ and $\mathrm{Sb}_{2} \mathrm{O}_{3}$ NPs were described (Xia et al. 2008; Bayat et al. 2014; Aruoja et al. 2015).

Intracellular (biotic) ROS can have origin in the endoplasmic reticulum, peroxisomes and in electron transport processes in mitochondria and chloroplasts (in eukaryotic photosynthetic organisms) (Lesser 2006; del Rio and Lopez-Huertas 2016) (Fig. 1E, bottom). MOx NPs, even containing redoxinactive metals, such as $\mathrm{NiO}$ (Siddiqui et al. 2012; Ahamed et al. 2013; Oukarroum et al. 2017; Sousa et al. 2018c; Sousa et al. 2018b) and ZnO NPs (De Berardis et al. 2010; Kumar et al. 2011; Alarifi et al. 2013; Lu et al. 2015; Ng et al. 2017) can induce intracellular ROS and oxidative stress. It was shown that $P$. subcapitata algal cells exposed to NiO NPs presented a reduced activity of the photosystem II ( $\phi$ PSII) and a decreased electron flow in the electron transport chain (ETC). The electrons deflected from photosynthetic ETC probably are used to generate ROS (Sousa et al. 2018b) (Fig. 1E, bottom). Compatible with this possibility, 
intracellular ROS accumulation and decrease of $\phi$ PSII were also observed in microalgae ( $P$. subcapitata or C. reinhardtii) exposed to $\mathrm{Al}_{2} \mathrm{O}_{3}, \mathrm{CeO}_{2}, \mathrm{Cr}_{2} \mathrm{O}_{3}, \mathrm{Mn}_{3} \mathrm{O}_{4}, \mathrm{SiO}_{2}$ or $\mathrm{SnO}_{2} \mathrm{NPs}$ (Rodea-Palomares et al. 2012; da Costa et al. 2016; Sousa et al. 2019b) and in the cyanobacterium Anabaena CPB4337 exposed to $\mathrm{CeO}_{2} \mathrm{NPs}$ (Rodea-Palomares et al. 2012).

It was proposed that in $P$. subcapitata cells exposed to $\mathrm{NiO}$ NPs, the disturbance of photosynthetic performance and the increase of intracellular ROS, combined with a reduction of metabolic (esterasic) activity may cause the arrest of algal cell cycle which, in turn, may origin the increase of cell volume and the appearance of aberrant morphology and, ultimately, the arrest of algal growth (Sousa et al. 2018b). Similarly, it was observed that $\mathrm{Al}_{2} \mathrm{O}_{3}, \mathrm{Mn}_{3} \mathrm{O}_{4}$ and $\mathrm{SiO}_{2} \mathrm{NPs}$ induced the growth inhibition of $P$. subcapitata as a consequence of the cumulative effect of adverse outcomes, such as intracellular ROS accumulation, loss of metabolic activity and reduction of $\phi$ PSII (Sousa et al. 2019b). A reduction of chlorophyll $a$ content and increase of ROS was also observed in C. minutissima exposed to $\mathrm{Co}_{3} \mathrm{O}_{4}$ NPs (Sharan and Nara 2020).

OS is associated with the damage of biological molecules such as cellular lipids (via lipid peroxidation, LPO), carbohydrates, proteins and DNA (Halliwell and Gutteridge 2015) being considered a major mechanism of NPs toxicity (Nel et al. 2006; $\mathrm{Xia}$ et al. 2006). Accordingly, $\mathrm{ROS}$ production by various $\mathrm{MOx}$ $\mathrm{NPs}$, namely, $\mathrm{Al}_{2} \mathrm{O}_{3}, \mathrm{Ce}_{2} \mathrm{O}, \mathrm{CuO}, \mathrm{Mn}_{3} \mathrm{O}_{4}, \mathrm{NiO}, \mathrm{SiO}_{2}, \mathrm{SnO}_{2}$, $\mathrm{TiO}_{2}$ and $\mathrm{ZnO}$ with the consequent cell oxidative disturbances, which include, LPO and cell membrane damage (loss of integrity), overwhelmed antioxidant defence system, reduced mitochondrial function, chromatin condensation, DNA damage and cell death via apoptotic pathway, over different biological models have been described; examples are the following: bacteria (Kumar et al. 2011; Rodea-Palomares et al. 2012), yeasts (Zhang et al. 2016; Babele et al. 2018; Sousa et al. 2018c; Sousa et al. 2019a), freshwater and marine microalgae (RodeaPalomares et al. 2012; von Moos et al. 2015; Xia et al. 2015; Suman et al. 2015; von Moos et al. 2016; Oukarroum et al. 2017; Dauda et al. 2017; Sendra et al. 2018; Sousa et al. 2018b; Sousa et al. 2019b), carp (Cyprinus carpio) larva (Naeemi et al. 2020) and human cell lines (Karlsson et al. 2008; Park et al. 2008; Lu et al. 2015; Duan et al. 2015; Rajiv et al. 2016; Subramaniam et al. 2020).

\section{Shading effect (on photosynthetic microorganisms): homoagglomeration of NPs}

MOx NPs, in aqueous medium, can interact with each other and form clusters of NPs (homoagglomerates), which can have an important impact on their bioavailability, fate in the environment and toxicity (Vale et al. 2016). The homoagglomeration process (as well as heteroagglomeration - please see below) depends on the concentration and characteristics of the NPs (chemical composition, morphology and charge), the NPs surface functionalisation, the physico-chemical properties of the medium where they are suspended, namely, IS (influenced by water salinity and hardness), $\mathrm{pH}$ of the solution (which affects the NPs surface charge) and the existence of natural organic matter (NOM). NOM can adsorb to the NPs surface and origin their steric stabilisation or act as bridges promoting the agglomeration of NPs (Amde et al. 2017; Yu et al. 2018). The adsorption of NOM to NPs, with the formation of coated NPs (corona-coated NPs), can be associated with the transfer of these NMs from algae to higher trophic levels consumers (crustaceans and fish) presenting unknown environmental and human health risks (Xu et al. 2020).

Aqueous suspensions of dispersed or homoagglomerated MOx NPs are, sometimes, opaque. Due to light absorption or scattering by NPs or NPs homoagglomerates, a reduction of the light availability can occur (shading effect, Fig. 1F). This effect can influence the photosynthetic efficiency of organisms like cyanobacteria and algae (Navarro et al. 2008). In agreement with this possibility, a significant decrease in light absorbance of $C$. reinhardtii algal suspensions, in comparison with control (NPs free), due to $\mathrm{CuO}$ NPs at concentrations higher than $1 \mathrm{mg} \mathrm{L}^{-1}$ was described (Cheloni et al. 2016). Sadiq et al. (2011) suggested that the growth inhibition and chlorophyll content reduction observed in algal cells incubated with $\mathrm{Al}_{2} \mathrm{O}_{3}$ could be attributed to the decrease of light availability owing to the attachment of the NPs onto cell wall of Chlorella spp. A shading effect was also attributed to Co NPs in the inhibition of S. costatum growth (Chen et al. 2018).

However, other authors did not observe any significant effect on the $72 \mathrm{~h}$ growth of the alga $P$. subcapitata, regardless of the concentrations of $\mathrm{CeO}_{2}, \mathrm{CuO}$ and $\mathrm{ZnO}$ NPs tested; in the case of $\mathrm{TiO}_{2}$, even for the relative opaque suspensions, containing easily settled NPs homoagglomerates, a growth reduction was not observed (Aruoja et al. 2009; Rogers et al. 2010; Hartmann et al. 2010). A shading effect was also excluded, as the main mechanism of $\mathrm{ZnO}$ nanotoxicity on Chlorella spp. (Ji et al. 2011) and $\mathrm{TiO}_{2}$ on K. brevis and $S$. costatum, although the algae were almost entirely covered by $\mathrm{TiO}_{2} \mathrm{NPs}$ agglomerates (Li et al. 2015). This means that, at least, for the organisms and NPs reported above, the shading effect does not appear to be the main mechanism of toxicity.

\section{Physical restraint: heteroagglomeration}

Another possibility of NPs inducing a toxic effect is through the co-agglomeration of NPs (or NPs homoagglomerates) with cells - formation of heteroagglomerates. These micro or even macroscopic heteroagglomerates can lead to the reduction of light, nutrients, or oxygen availability, due to the trapping of cells inside the agglomerates (Fig. 1G). In this context, Aruoja et al. (2009) described the co-agglomeration of $\mathrm{TiO}_{2} \mathrm{NPs}$ with algal cells of $P$. subcapitata; the formation of large clusters entrapped almost all algae. Thus, it was suggested that the 
observed growth inhibition could be attributed to the reduced availability of light in entrapped cells. According to the authors, the shading effect may contribute (or play a major role) to the toxicity of $\mathrm{TiO}_{2}$ NPs on algae. A similar mechanism (limitation of essential nutrients due to physical restriction caused by heteroagglomeration) has been proposed for cyanobacterium cells exposed to $\mathrm{CeO}_{2} \mathrm{NPs}$; bacteria incubated with $\mathrm{CeO}_{2}$ NPs were found completely entrapped inside the heteroagglomerates, which leads the authors not to exclude the possibility that the nutrients transport into the cells may have been severely impaired (Rodea-Palomares et al. 2011). However, phosphate or micronutrients depletion, due to the adsorption on NPs surface, alone, did not allow to explain $\mathrm{CeO}_{2}$ toxicity to $P$. subcapitata (Rogers et al. 2010).

The formation of heteroagglomerates and the respective algal entrapment, may, by itself, not induce a toxic effect. In fact, it was reported that $\mathrm{Al}_{2} \mathrm{O}_{3}, \mathrm{Mn}_{3} \mathrm{O}_{4}$ and $\mathrm{SnO}_{2}$ NPs form heteroagglomerates with algal cells. The observation of cells inside, at the periphery of the structures and in the surrounding medium, together with the easy dispersibility of the agglomerates makes it hardly plausible that the toxicity induced by these NPs may be due to nutritional limitations induced by hetero agglomeration (Sousa et al. 2019b).

\section{Yeast responses to MOx NPs stress}

Although different yeasts have been used in the assessment of antifungal properties of MOx NPs, the main workhorse in ecotoxicity studies with these NMs is the yeast $S$. cerevisiae. Thus, unless stated otherwise, when in the text below it is mentioned the word "yeast", it means S. cerevisiae.

The knowledge of the cellular responses (toxic symptoms exhibited by yeasts) to MOx NPs (described below and depicted in Fig. 2) is important in the identification of potential targets and biomarkers of the toxic action of NPs. Additionally, these information can be useful in the elucidation of the specific modes of action by which MOx NPs interact with the eukaryotic cells and affect their physiology and metabolism.

\section{Inhibition of cell proliferation}

The impact of MOx NPs on the ability of a cell to divide (yeast proliferation) has been evaluated either by a clonogenic assay (viability assay) or in a liquid culture medium (growth inhibition assay). A reduction of the $\%$ of viability, in a dosedependent way, was observed when yeast cells were exposed to different NPs: $\mathrm{Al}_{2} \mathrm{O}_{3}, \mathrm{NiO}, \mathrm{Mn}_{3} \mathrm{O}_{4}, \mathrm{SiO}_{2}$ and $\mathrm{SnO}_{2}$ (Sousa et al. 2018a; Sousa et al. 2019a). 24 h-IC $\mathrm{IC}_{50}$ values of $4.8 \mathrm{mg} / \mathrm{L}$ $\mathrm{CuO}$ (Kasemets et al. 2013) and 5-20 mg/L ZnO (Babele et al. 2018) were described. Higher NPs concentrations were required to inhibit growth. Thus, yeast growth inhibition, in rich medium, was described for $\mathrm{CuO}\left(8 \mathrm{~h}-\mathrm{EC}_{50}\right.$ of $\left.20.7 \mathrm{mg} / \mathrm{L}\right)$ and for $\mathrm{ZnO}$ NPs ( 8 h-EC 50 121-134 mg/L) in malt extract (ME) medium (Kasemets et al. 2009). However, no growth inhibition in yeast peptone dextrose (YPD) broth was observed when yeast cells were exposed to $100 \mathrm{mg} / \mathrm{L} \mathrm{Al}_{2} \mathrm{O}_{3}, \mathrm{NiO}, \mathrm{Mn}_{3} \mathrm{O}_{4}$, $\mathrm{SiO}_{2}$, and $\mathrm{SnO}_{2}$ NPs (Sousa et al. 2018a; Sousa et al. 2019a).

The incubation of yeast cells in water or a buffer solution revealed to be a more sensitive method for the assessment of MOx NPs toxicity rather than protein-rich liquid culture medium (ME or YPD) (Kasemets et al. 2013; Suppi et al. 2015; Sousa et al. 2018a; Sousa et al. 2019a). This difference of sensitivity can be partially explained by the presence of proteins in the culture media which can be adsorbed to NPs, and form a protein layer, which is called protein corona (Kharazian et al. 2016); the "coating" of MOx NPs with proteins can reduce their toxicity (Nguyen and Lee 2017). Additionally, the organic ligands, in rich medium, complex the toxic ions making them less bioavailable and thus less toxic (Hughes and Poole 1991).

\section{Cell wall damage}

The exposure of $S$. cerevisiae to $\mathrm{ZnO}$ NPs induced cell wall damage (Babele et al. 2018). Yeasts with morphology changed from elliptical to irregular shape and with cell wall deformed, with sunken areas or deficiencies or even broken or partially broken were described after being exposed to $\mathrm{ZnO}$ NPs (Zhang et al. 2016). Yeast cells treated with $\mathrm{TiO}_{2}$ and $\mathrm{CuO}$ NPs presented the wall with an undulating appearance. In cells exposed to $\mathrm{CuO}$ NPs, a cell wall with a thicker and folded appearance was also described (Bayat et al. 2014).

Mutant strains with deficient genes associated with cell wall organization and biogenesis (such as KRE6, HOC1 and $B C K 1)$ were more sensitive to $\mathrm{ZnO}$ NPs than the respective wild-type strain; the increased susceptibility of $\mathrm{ZnO}$ treated cells to sonication confirmed that ZnO NPs affected cell wall function and integrity (Márquez et al. 2018).

An increase in the chitin content, a marker of cell wall stress and an upregulation in the expression of chitin synthesis (CHS1, CHS3 and CHS5) genes were described in S. cerevisiae treated with ZnO NPs (Babele et al. 2018). Similarly, the yeast Pichia pastoris incubated with $\mathrm{TiO}_{2}$ NPs presented an increased chitin content in the cell wall (Liu et al. 2016).

\section{Modification of metabolic activity}

Another option used to assess the toxicity of MOx NPs in yeasts is to evaluate its impact on the general metabolic status of the cells. For this purpose, different fluorescent probes have been used such as fluorescein diacetate (FDA), 2-chloro4-(2,3-dihydro-3-methyl-(benzo-1,3-thiazol-2-yl)methylidene)-1-phenylquinolinium iodide (FUN-1), and resazurin (Alamar Blue reagent). Yeast cells exposed to 


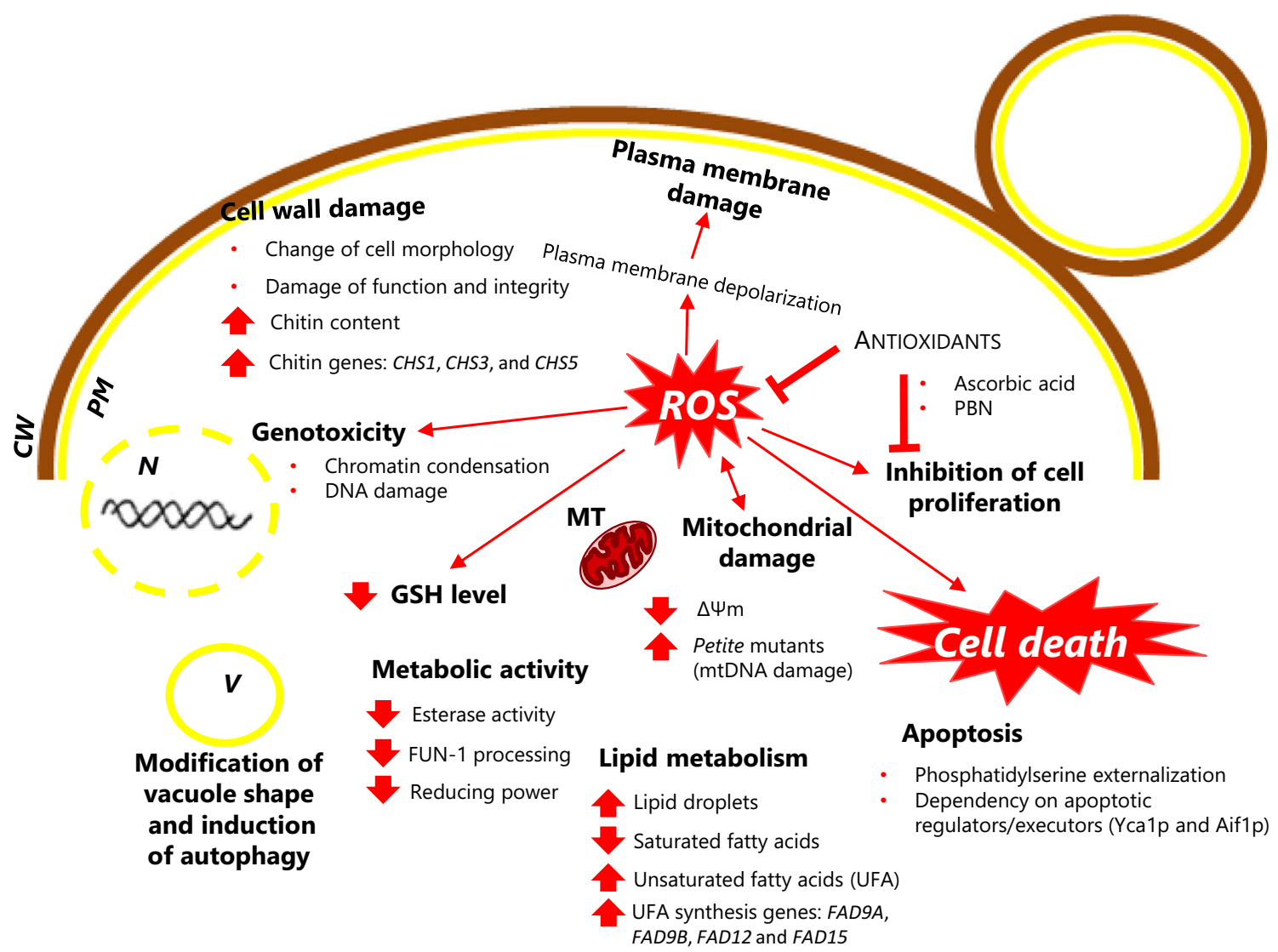

Fig. 2 Schematic representation of the principal molecular and physiological yeast responses to metal(loid) oxide nanoparticles. Please see text for details. CW, cell wall; $\Delta \Psi \mathrm{m}$, mitochondrial membrane potential; FUN-1, 2-chloro-4-(2,3-dihydro-3-methyl-(benzo-1,3-thiazol-

$\mathrm{CuO}$ NPs presented a reduction of metabolic (reductase) activity (Mashock et al. 2016). In the same way, yeasts treated with $\mathrm{Al}_{2} \mathrm{O}_{3}, \mathrm{Mn}_{3} \mathrm{O}_{4}, \mathrm{NiO}, \mathrm{SiO}_{2}$ and $\mathrm{SnO}_{2}$ NPs presented a reduced metabolic capability traduced by a decreased ability to process the probe FUN-1 and by a diminished esterase activity (Sousa et al. 2018a; Sousa et al. 2019a). It was suggested that the reduction of esterasic activity could be a consequence of OS (Sousa et al. 2019a), since intracellular ROS accumulation could lead to the oxidation of sensitive amino acid residues of the enzymes, such as those containing aromatic side chain or sulfhydryl groups (Cecarini et al. 2007).

A disturbance in lipids biosynthesis was described in yeasts treated with MOx NPs. The modification in the cellular distribution of lipid biosynthetic enzymes (Fas1 and Fas2) and the induction and accumulation of lipids droplets (LDs) in yeast cells treated with $\mathrm{ZnO}$ (Babele et al. 2018) or CuO NPs (Bayat et al. 2014) was observed. In the same way, an enhancement in LDs, a decrease of the relative content of saturated fatty acids, an increase of the content of unsaturated fatty acids (UFA), and an upregulation of the genes involved in UFA synthesis (FAD9A, FAD9B, FAD12 and FAD15) was described in the yeast $P$. pastoris exposed to $\mathrm{TiO}_{2}$ NPs $(\mathrm{Yu}$ et al. 2015). 2-yl)-methylidene)-1-phenylquinolinium iodide; GSH, reduced glutathione; MT, mitochondria; mtDNA, mitochondrial DNA; N, nucleus; NPs, nanoparticles; PBN, N-tertbutyl- $\alpha$-phenylnitrone; PM, plasma membrane; ROS, reactive oxygen species; V, vacuole

Using powerful techniques such as proteomics, metabolomics and system biology-based pathway analysis it was found that in S. cerevisiae cells exposed to $\mathrm{ZnO}$ NPs, almost $40 \%$ of proteins are down regulated and the metabolome deregulated. More specifically, it was found that a wide range of key metabolites involved in central carbon metabolism, cofactors synthesis, amino acid and fatty acid biosynthesis, purines and pyrimidines, nucleoside and nucleotide biosynthetic pathways were repressed (Babele 2019). By a similar approach (transcriptomic and proteome profile analysis), it was found that $\mathrm{ZnO}$ and $\mathrm{ZnFe}_{2} \mathrm{O}_{4}$ NPs induced dysfunction of cholesterol biosynthesis in an alveolar rat macrophage cell line (Doumandji et al. 2020).

\section{Intracellular ROS generation}

S. cerevisiae cells exposed to $\mathrm{Al}_{2} \mathrm{O}_{3}, \mathrm{Mn}_{3} \mathrm{O}_{4}, \mathrm{NiO}, \mathrm{SiO}_{2}$, $\mathrm{SnO}_{2}$ and $\mathrm{ZnO}$ NPs accumulated significantly more intracellular ROS than control (Zhang et al. 2016; Babele et al. 2018; Sousa et al. 2018c; Sousa et al. 2019a). The co-incubation of yeast cells with $\mathrm{Al}_{2} \mathrm{O}_{3}, \mathrm{Mn}_{3} \mathrm{O}_{4}, \mathrm{NiO}, \mathrm{SiO}_{2}$ and $\mathrm{SnO}_{2} \mathrm{NPs}$ and the antioxidants ascorbic acid or N-tertbutyl- $\alpha$-phenylnitrone quenched intracellular ROS and significantly restored cell 
viability and metabolic activity, suggesting a ROS-mediated mechanism in cytotoxicity induced by these NPs over yeast cells (Sousa et al. 2018c; Sousa et al. 2019a). $\mathrm{TiO}_{2}$ NPs also induced a dose-dependent accumulation of intracellular ROS in the yeast $P$. pastoris (Chen et al. 2019).

Mitochondrial respiratory chain seems to be an important source of ROS since wild-type yeast cells under nitrogen atmosphere as well as mutants lacking respiratory chain (without mitochondrial DNA, $\rho^{0}$ ) presented decreased intracellular levels of ROS and augmented resistance to NiO NPs (Sousa et al. 2018c). It was hypothesised that the $\mathrm{Ni}$ ions released from NPs can disturb the electron transport at mitochondria by displacing iron from the ETC of the inner mitochondrial membrane. Probably, the leakage of electrons from the ETC to oxygen lead to the production of $\mathrm{O}_{2}{ }^{-}{ }^{-}$which, in turn, is most likely the main origin of $\mathrm{H}_{2} \mathrm{O}_{2}$ (Sousa et al. 2018c). In fact, both ROS types $\left(\mathrm{O}_{2} \cdot{ }^{-}\right.$and $\left.\mathrm{H}_{2} \mathrm{O}_{2}\right)$ were detected in S. cerevisiae cells treated with $\mathrm{NiO}$ NPs (Sousa et al. 2018c).

Transcriptomic analysis revealed that $\mathrm{Y}_{3} \mathrm{O}_{3}$ NPs, at high concentration $\left(1-4 \mathrm{~g} \mathrm{~L}^{-1}\right)$, induced the upregulation of oxidative stress genes in S. cerevisiae (Moriyama et al. 2019).

\section{Reduction of non-enzymatic and enzymatic antioxi- dant defences}

Yeast cells present non-enzymatic (which the most abundant is reduced glutathione, GSH) and enzymatic defence mechanisms such as superoxide dismutases (SOD1 and SOD2), catalases (CatT and CatA), glutathione peroxidases (such as Gpx3 and Grx1) and thioredoxin peroxidases (like, Tsa 1 and Prx1) to preserve intracellular redox equilibrium and survive (Jamieson 1998; Herrero et al. 2008).

Reduced glutathione seems to be involved in the fight against $\mathrm{OS}$ induced by $\mathrm{NiO}$ as revealed by the decrease of cellular GSH level in yeasts incubated with these NPs. Supporting this observation, it was shown that mutant strains without $(g s h 1 \Delta)$ or with a reduced level of GSH $(g s h 2 \Delta)$ presented augmented levels of ROS and susceptibility to NiO NPs (Sousa et al. 2018c). The depletion of the GSH levels can be a consequence of the increased consumption in the scavenging of free oxygen radicals induced by NPs or due to the affinity of metal ions (such as $\mathrm{Ni}^{2+}$ ) to cysteine residue of $\mathrm{GSH}$, leading to a reduction of cellular antioxidant defences (Sousa et al. 2018c). Similarly, $\mathrm{TiO}_{2}$ NPs induced an accentuated reduction in GSH concentration in the yeast P. pastoris (Liu et al. 2016).

Single-gene mutant strains devoid of the main antioxidant enzymatic defences (Sod1p, Sod2p, Ctt1p, Cta1p, Gpx3p, Grxlp, Tsalp and Pprxlp) did not present augmented vulnerability to NiO NPs comparatively to wild-type strain (Sousa et al. 2018c); the absence of a sensitive phenotype, in these deleted strains, can be attributed to gene redundancy or the presence of compensatory parallel pathways (Dawes 2004). A similar effect was observed with sod $1 \Delta$ and $\operatorname{sod} 2 \Delta$ mutant strains exposed to
CuO NPs (Kasemets et al. 2013). However, the yeast P. pastoris treated with $\mathrm{TiO}_{2} \mathrm{NPs}$ presented a downregulation of the genes (cSOD, GLR1, GPXI and TRR1) encoding to enzymes associated with ROS scavenging system (Liu et al. 2016).

\section{Loss of cell membrane integrity}

One of the outcomes of high ROS levels is the lipid peroxidation. Large-scale lipid peroxidation leads to increased membrane fluidity, efflux of cytosolic components and, ultimately, loss of plasma membrane integrity and cell death (Avery 2011). Consistent with this scenario, it was shown that the exposure of yeasts to NiO NPs leads to a progressive depolarization (reduction of the membrane potential) and an increase of permeability of the yeast plasma membrane, in cells under oxidative stress (Sousa et al. 2019c). Similarly, yeasts incubated with ZnO NPs displayed intracellular ROS and an augmented cell membrane permeability (Babele et al. 2018). It was observed that strains with deletion of genes involved in the biosynthesis of ergosterol (ERG2 and ERG28), a sterol that affects membrane fluidity, and in transmembrane transport ( $P K R 1)$, displayed enhanced susceptibility to $\mathrm{ZnO}$ NPs, which suggested that these NPs disrupt cell membrane integrity and impair their proper function (transport) (Márquez et al. 2018).

The impact of MOx NPs on yeast cell membrane can be dose-dependent. Thus, the incubation of yeasts for $24 \mathrm{~h}$ with $100 \mathrm{mg} \mathrm{L} \mathrm{Al}_{2} \mathrm{O}_{3}, \mathrm{In}_{2} \mathrm{O}_{3}, \mathrm{Mn}_{3} \mathrm{O}_{4}, \mathrm{SiO}_{2}$ and $\mathrm{SnO}_{2}$ did not induce the permeabilization of the cell membrane (Sousa et al. 2019a). However, the exposure of the same yeasts to some of these NPs $\left(\mathrm{Al}_{2} \mathrm{O}_{3}, \mathrm{Mn}_{2} \mathrm{O}_{3}\right.$ and $\left.\mathrm{SiO}_{2}\right)$, but at higher concentration $\left(1000 \mathrm{mg} \mathrm{L}^{-1}\right)$, during $10 \mathrm{~h}$, caused a significant loss of membrane integrity (Garcia-Saucedo et al. 2011; Otero-Gonzalez et al. 2013).

\section{Alteration of function and morphology of mitochondria and endoplasmic reticulum}

Mitochondrial membrane potential $\left(\Delta \Psi_{\mathrm{m}}\right)$ is an essential component for energy-producing and non-producing mitochondrial functions (Zorova et al. 2018). The depolarization of the mitochondrial membrane, i.e. the dissipation of mitochondrial membrane potential in yeast cells treated with $\mathrm{NiO}$ NPs (Sousa et al. 2019c) and the alteration of the architecture of mitochondria in cells incubated with $\mathrm{ZnO}$ NPs were described (Babele et al. 2018).

The exposure to $\mathrm{ZnO}$ NPs also severely affected the architecture and function of the endoplasmic reticulum, in yeasts, through modulation of unfolded protein response (Babele et al. 2018). 


\section{Modification of vacuole architecture and induction of autophagy}

Yeast cells treated with ZnO NPs presented a drastic modification of vacuoles morphology (Bayat et al. 2014; Babele et al. 2018) and a redistribution of Atg8-GFP to vacuoles, indicating the induction of autophagy (Babele et al. 2018). It was observed (by TEM) the modification of vacuole shape and its disruption, in yeasts incubated with $\mathrm{TiO}_{2}$ and $\mathrm{CuO}$ NPs, respectively. Dark deposits in vacuoles $\left(\mathrm{TiO}_{2}\right.$ treated cells) or in vesicles $(\mathrm{ZnO}$ or $\mathrm{CuO}$ treated cells) were also described (Bayat et al. 2014).

\section{Mitochondrial and genomic DNA damage}

DNA damage is commonly found during OS, being mitochondrial DNA (mtDNA) a very sensitive target (Richter et al. 1988). Exposure of $S$. cerevisiae cells to NiO NPs led to the mtDNA damage with the consequent abolition of respiration (incapacity to grow on non-fermentable carbon sources) and the formation of typical respiratory-deficient colonies, commonly known as petite mutants (Sousa et al. 2019c).

Using the canavanine assay, it was shown the damage of nuclear DNA in yeasts incubated with NiO NPs (Sousa et al. 2019c). Nuclear DNA damage, measured using the comet assay, in yeast cells treated with $\mathrm{CuO}, \mathrm{TiO}_{2}$ and $\mathrm{ZnO}$ NPs was also described (Bayat et al. 2014).

\section{Apoptotic cell death}

The exposure of yeast cells to NiO NPs induced regulated cell death, with typical apoptotic hallmarks such as damage of cell membrane, loss of cell viability, phosphatidylserine exposure at the outer cytoplasmic membrane leaflet, and nuclear chromatin condensation, in a process dependent on de novo protein synthesis and apoptotic regulators/executors (Ycalp and Aiflp) (Sousa et al. 2019c). The sequence of events associated with the induction of cell death in S. cerevisiae by NiO NPs was described (Sousa et al. 2019c). Other studies also indicated a cell dead apoptotic pathway in human cell lines exposed to $\mathrm{CuO}$ (Siddiqui et al. 2013), $\mathrm{NiO}$ (Siddiqui et al. 2012), $\mathrm{ZnO}$ (Keerthana and Kumar 2020), or binary mixtures of $\mathrm{Al}_{2} \mathrm{O}_{3}$ and ZnO NPs (Koerich et al. 2020).

\section{Concluding remarks}

Products containing NMs grown enormously in the last decades. Nanotechnology Consumer Products Inventory, updated in 2013, listed 1814 consumer products containing NMs, from 622 companies, in which products containing metals and metal oxides correspond to the largest group, constituting 37\% of products (Vance et al. 2015). Concomitant, and understandably, concerns about environmental, health and safety implications of NMs have also raised.

Over the last decade, and thanks to a substantial research effort, important progress concerning the impact of NPs in terrestrial and aquatic systems as well as about their mechanisms of toxicity has been observed. However, substantial gaps still exist that require further attention, namely regarding to MOx NPs concentrations used in the assays, the time and the type of exposure.

Although it is difficult to accurately detect NPs in aquatic environments, it is estimated that their concentration in surface waters varies from $\mathrm{ng} \mathrm{L}^{-1}$ to $\mu \mathrm{g} \mathrm{L}^{-1}$ (Gottschalk et al. 2013). However, it is common to find studies that use NPs concentrations greater than $100 \mathrm{mg} \mathrm{L}^{-1}$, reaching $1000 \mathrm{mg}$ $\mathrm{L}^{-1}$ or even more. Another challenge is to study the impact of sub-lethal concentrations of NPs during a long-term exposure (covering multiple generations of the organism), in a repeated way, to get more information on chronic exposure to MOx NPs, in order to adopt the necessary protective measures regarding the use of products containing MOx NPs.

A more systematic approach is needed in nanotoxicology research. Thus, future studies should combine high-throughput molecular profiling technologies (transcriptomics, proteomics and metabolomics) with more traditional approaches (physiological studies), to give a holistic understanding of cellular responses to MOx NPs (and NMs in a general way) and allow the elucidation of the mechanisms associated with its toxicity.

Author contribution ES and HS conceived the review. ES and HS wrote the manuscript. ES conceived and designed the figures. All authors read and approved the manuscript.

Funding This work was supported by National funds through FCT Foundation for Science and Technology under the scope of the projects UIDB/50006/2020, UID/BIO/04469/2020 unit and BioTecNorte operation (NORTE-01-0145-FEDER-000004) funded by the European Regional Development Fund under the scope of Norte2020 - Programa Operacional Regional do Norte.

\section{Declarations}

This article does not contain any studies with human participants or animals performed by any of the authors.

Conflict of interest The authors declare no competing interests.

\section{References}

Ahamed M, Ali D, Alhadlaq HA, Akhtar MJ (2013) Nickel oxide nanoparticles exert cytotoxicity via oxidative stress and induce apoptotic response in human liver cells (HepG2). Chemosphere 93:25142522. https://doi.org/10.1016/j.chemosphere.2013.09.047

Alarifi S, Ali D, Alkahtani S, Verma A, Ahamed M, Ahmed M, Alhadlaq HA (2013) Induction of oxidative stress, DNA damage, and apoptosis in a malignant human skin melanoma cell line after exposure to 
zinc oxide nanoparticles. Int J Nanomedicine 8:983-993. https://doi. org/10.2147/IJN.S42028

Amde M, Liu J-F, Tan Z-Q, Bekana D (2017) Transformation and bioavailability of metal oxide nanoparticles in aquatic and terrestrial environments. A review. Environ Pollut 230:250-267. https://doi. org/10.1016/j.envpol.2017.06.064

Angel BM, Vallotton P, Apte SC (2015) On the mechanism of nanoparticulate $\mathrm{CeO}_{2}$ toxicity to freshwater algae. Aquat Toxicol 168:90-97. https://doi.org/10.1016/j.aquatox.2015.09.015

Anissimova OV, Staer OV (2018) Morphology of cell wall pore channels in the genus Euastrum ralfs (Desmidiales). Moscow Univ Biol Sci Bull 73:28-31. https://doi.org/10.3103/S0096392518010029

Aravantinou AF, Tsarpali V, Dailianis S, Manariotis ID (2015) Effect of cultivation media on the toxicity of $\mathrm{ZnO}$ nanoparticles to freshwater and marine microalgae. Ecotoxicol Environ Saf 114:109-116. https://doi.org/10.1016/j.ecoenv.2015.01.016

Argueello JM, Raimunda D, Gonzalez-Guerrero M (2012) Metal transport across biomembranes: emerging models for a distinct chemistry. J Biol Chem 287:13510-13517. https://doi.org/10.1074/jbc. R111.319343

Aruoja V, Dubourguier H-C, Kasemets K, Kahru A (2009) Toxicity of nanoparticles of $\mathrm{CuO}, \mathrm{ZnO}$ and $\mathrm{TiO}_{2}$ to microalgae Pseudokirchneriella subcapitata. Sci Total Environ 407:14611468. https://doi.org/10.1016/j.scitotenv.2008.10.053

Aruoja V, Pokhrel S, Sihtmaae M, Mortimer M, Maedler L, Kahru A (2015) Toxicity of 12 metal-based nanoparticles to algae, bacteria and protozoa. Environ Sci 2:630-644. https://doi.org/10.1039/ c5en00057b

Avery SV (2011) Molecular targets of oxidative stress. Biochem J 434: 201-210. https://doi.org/10.1042/BJ20101695

Babele PK (2019) Zinc oxide nanoparticles impose metabolic toxicity by de-regulating proteome and metabolome in Saccharomyces cerevisiae. Toxicol REPORTS 6:64-73. https://doi.org/10.1016/j. toxrep.2018.12.001

Babele PK, Thakre PK, Kumawat R, Tomar RS (2018) Zinc oxide nanoparticles induce toxicity by affecting cell wall integrity it pathway, mitochondrial function and lipid homeostasis in Saccharomyces cerevisiae. Chemosphere 213:65-75. https://doi.org/10.1016/j. chemosphere.2018.09.028

Balusamy B, Tastan BE, Ergen SF, Uyar T, Tekina T (2015) Toxicity of lanthanum oxide $\left(\mathrm{La}_{2} \mathrm{O}_{3}\right)$ nanoparticles in aquatic environments. Environ Sci IMPACTS 17:1265-1270. https://doi.org/10.1039/ c5em00035a

Bao S, Lu Q, Fang T, Dai H, Zhang C (2015) Assessment of the toxicity of $\mathrm{CuO}$ nanoparticles by using Saccharomyces cerevisiae mutants with multiple genes deleted. Appl Environ Microbiol 81:80988107. https://doi.org/10.1128/AEM.02035-15

Bayat N, Rajapakse K, Marinsek-Logar R, Drobne D, Cristobal S (2014) The effects of engineered nanoparticles on the cellular structure and growth of Saccharomyces cerevisiae. Nanotoxicology 8:363-373. https://doi.org/10.3109/17435390.2013.788748

Bondarenko O, Ivask A, Kaekinen A, Kahru A (2012) Sub-toxic effects of $\mathrm{CuO}$ nanoparticles on bacteria: kinetics, role of $\mathrm{Cu}$ ions and possible mechanisms of action. Environ Pollut 169:81-89. https:// doi.org/10.1016/j.envpol.2012.05.009

Braconi D, Bernardini G, Santucci A (2016) Saccharomyces cerevisiae as a model in ecotoxicological studies: a post-genomics perspective. J Proteomics 137:19-34. https://doi.org/10.1016/j.jprot.2015.09.001

Brunner TJ, Wick P, Manser P, Spohn P, Grass RN, Limbach LK, Bruinink A, Stark WJ (2006) In vitro cytotoxicity of oxide nanoparticles: comparison to asbestos, silica, and the effect of particle solubility. Environ Sci Technol 40:4374 4381. https://doi.org/10.1021/ es052069i

Bundschuh M, Filser J, Luderwald S, Mckee MS, Metreveli G, Schaumann GE, Schulz R, Wagner S (2018) Nanoparticles in the environment: where do we come from, where do we go to? Environ Sci Eur 30. https://doi.org/10.1186/s12302-018-0132-6

Cecarini V, Gee J, Fioretti E, Amici M, Angeletti M, Eleuteri AM, Keller JN (2007) Protein oxidation and cellular homeostasis: emphasis on metabolism. Biochim Biophys Acta-Mol Cell Res 1773:93-104. https://doi.org/10.1016/j.bbamcr.2006.08.039

Cheloni G, Marti E, Slaveykova VI (2016) Interactive effects of copper oxide nanoparticles and light to green alga Chlamydomonas reinhardtii. Aquat Toxicol 170:120-128. https://doi.org/10.1016/j. aquatox.2015.11.018

Chen L, Zhou L, Liu Y, Deng S, Wu H, Wang G (2012) Toxicological effects of nanometer titanium dioxide $\left(\right.$ nano- $\left.\mathrm{TiO}_{2}\right)$ on Chlamydomonas reinhardtii. Ecotoxicol Environ Saf 84:155-162. https://doi.org/10.1016/j.ecoenv.2012.07.019

Chen X, Zhang C, Tan L, Wang J (2018) Toxicity of Co nanoparticles on three species of marine microalgae. Environ Pollut 236:454-461. https://doi.org/10.1016/j.envpol.2018.01.081

Chen F, Xiao Z, Yue L, Wang J, Feng Y, Zhu X, Wang Z, Xing B (2019) Algae response to engineered nanoparticles: current understanding, mechanisms and implications. Environ Sci 6:1026-1042. https:// doi.org/10.1039/c8en01368c

Cohen D, Soroka Y, Ma'or Z, Oron M, Portugal-Cohen M, Bregegere FM, Berhanu D, Valsami-Jones E, Hai N, Milner Y (2013) Evaluation of topically applied copper(II) oxide nanoparticle cytotoxicity in human skin organ culture. Toxicol Vitr 27:292-298. https://doi.org/10.1016/j.tiv.2012.08.026

Condello M, De Berardis B, Ammendolia MG, Barone F, Condello G, Degan P, Meschini S (2016) ZnO nanoparticle tracking from uptake to genotoxic damage in human colon carcinoma cells. Toxicol Vitr 35:169-179. https://doi.org/10.1016/j.tiv.2016.06.005

Cronholm P, Karlsson HL, Hedberg J, Lowe TA, Winnberg L, Elihn K, Wallinder IO, Moeller L (2013) Intracellular uptake and toxicity of $\mathrm{Ag}$ and $\mathrm{CuO}$ nanoparticles: a comparison between nanoparticles and their corresponding metal ions. SMALL 9:970-982. https://doi.org/ 10.1002/smll.201201069

Czyzowska A, Barbasz A (2020) A review: zinc oxide nanoparticlesfriends or enemies? Int J Environ Health Res. https://doi.org/10. 1080/09603123.2020.1805415

da Costa CH, Perreault F, Oukarroum A, Melegari SP, Popovic R, Matias WG (2016) Effect of chromium oxide (III) nanoparticles on the production of reactive oxygen species and photosystem II activity in the green alga Chlamydomonas reinhardtii. Sci Total Environ 565:951-960. https://doi.org/10.1016/j.scitotenv.2016.01.028

Dauda S, Chia MA, Bako SP (2017) Toxicity of titanium dioxide nanoparticles to Chlorella vulgaris Beyerinck (Beijerinck) 1890 (Trebouxiophyceae, Chlorophyta) under changing nitrogen conditions. Aquat Toxicol 187:108-114. https://doi.org/10.1016/j. aquatox.2017.03.020

Dawes IW (2004) Stress responses. In: Dickinson JR, Schweizer M (eds) The metabolism and molecular physiology of Saccharomyces cerevisiae, 2nd edn. Taylor and Francis, Ltd, London, pp 376-439

De Berardis B, Civitelli G, Condello M, Lista P, Pozzi R, Arancia G, Meschini S (2010) Exposure to $\mathrm{ZnO}$ nanoparticles induces oxidative stress and cytotoxicity in human colon carcinoma cells. Toxicol Appl Pharmacol 246:116-127. https://doi.org/10.1016/j.taap.2010. 04.012

Dekkers S, Williams TD, Zhang J, Zhou J, Vandebriel RJ, la Fonteyne LJJ, Gremmer ER, He S, Guggenheim EJ, Lynch I, Cassee FR, De Jong WH, Viant MR (2018) Multi-omics approaches confirm metal ions mediate the main toxicological pathways of metal-bearing nanoparticles in lung epithelial A549 cells. Environ Sci 5:15061517. https://doi.org/10.1039/c8en00071a

del Rio LA, Lopez-Huertas E (2016) ROS generation in peroxisomes and its role in cell signaling. PLANT CELL Physiol 57:1364-1376. https://doi.org/10.1093/pcp/pcw076 
Deniel M, Errien N, Daniel P, Caruso A, Lagarde F (2019) Current methods to monitor microalgae-nanoparticle interaction and associated effects. Aquat Toxicol 217:217. https://doi.org/10.1016/j. aquatox.2019.105311

dos Santos SC, Sa-Correia I (2015) Yeast toxicogenomics: lessons from a eukaryotic cell model and cell factory. Curr Opin Biotechnol 33: 183-191. https://doi.org/10.1016/j.copbio.2015.03.001

dos Santos S, Teixeira M, Cabrito T, Sá-Correia I (2012) Yeast toxicogenomics: genome-wide responses to chemical stresses with impact in environmental health, pharmacology, and biotechnology. Front Genet 3:63. https://doi.org/10.3389/fgene.2012.00063

Doumandji Z, Safar R, Lovera-Leroux M, Nahle S, Cassidy H, Matallanas D, Rihn B, Ferrari L, Joubert O (2020) Protein and lipid homeostasis altered in rat macrophages after exposure to metallic oxide nanoparticles. Cell Biol Toxicol 36:65-82. https://doi.org/10. 1007/s10565-019-09484-6

Duan W-X, He M-D, Mao L, Qian F-H, Li Y-M, Pi H-F, Liu C, Chen CH, Lu Y-H, Cao Z-W, Zhang L, Yu Z-P, Zhou Z (2015) NiO nanoparticles induce apoptosis through repressing SIRT1 in human bronchial epithelial cells. Toxicol Appl Pharmacol 286:80-91. https:// doi.org/10.1016/j.taap.2015.03.024

ECHA - European Chemicals Agency 2020 Nanomaterials. https://echa. europa.eu/regulations/nanomaterials. Accessed 7 Aug 2020

EPA - United States Environmental Protection Agency (2017) Nanomaterials - technical fact sheet. EPA 505-F-17-002

FDA - Food and Drug Administration (2018) Microorganisms \& microbial-derived ingredients used in food (partial list). In: FDA. https://www.fda.gov/food/generally-recognized-safe-gras/ microorganisms-microbial-derived-ingredients-used-food-partiallist. Accessed 7 Aug 2020

Foury F (1997) Human genetic diseases: a cross-talk between man and yeast. Gene 195:1-10. https://doi.org/10.1016/S0378-1119(97) 00140-6

Franklin NM, Rogers NJ, Apte SC, Batley GE, Gadd GE, Casey PS (2007) Comparative toxicity of nanoparticulate $\mathrm{ZnO}$, bulk $\mathrm{ZnO}$, and $\mathrm{ZnCl}_{2}$ to a freshwater microalga (Pseudokirchneriella subcapitata): the importance of particle solubility. Environ Sci Technol 41:8484-8490. https://doi.org/10.1021/es071445r

Garcia-Saucedo C, Field JA, Otero-Gonzalez L, Sierra-Alvarez R (2011) Low toxicity of $\mathrm{HfO}_{2}, \mathrm{SiO}_{2}, \mathrm{Al}_{2} \mathrm{O}_{3}$ and $\mathrm{CeO}_{2}$ nanoparticles to the yeast, Saccharomyces cerevisiae. J Hazard Mater 192:1572-1579. https://doi.org/10.1016/j.jhazmat.2011.06.081

Giaever G, Nislow C (2014) The yeast deletion collection: a decade of functional genomics. Genetics 197:451-465. https://doi.org/10. 1534/genetics.114.161620

Goffeau A, Barrell BG, Bussey H, Davis RW, Dujon B, Feldmann H, Galibert F, Hoheisel JD, Jacq C, Johnston M, Louis EJ, Mewes HW, Murakami Y, Philippsen P, Tettelin H, Oliver SG (1996) Life with 6000 genes. Science (80- ) 274:546. https://doi.org/10.1126/science. 274.5287.546

Gottschalk F, Sun T, Nowack B (2013) Environmental concentrations of engineered nanomaterials: review of modeling and analytical studies. Environ Pollut 181:287-300. https://doi.org/10.1016/j.envpol. 2013.06.003

Guerra FD, Attia MF, Whitehead DC, Alexis F (2018) Nanotechnology for environmental remediation: materials and applications. MOLECULES 23. https://doi.org/10.3390/molecules23071760

Guo Y, Cheng C, Wang J, Wang Z, Jin X, Li K, Kang P, Gao J (2011) Detection of reactive oxygen species (ROS) generated by $\mathrm{TiO}_{2}(\mathrm{R})$, $\mathrm{TiO}_{2}(\mathrm{R} / \mathrm{A})$ and $\mathrm{TiO}_{2}(\mathrm{~A})$ under ultrasonic and solar light irradiation and application in degradation of organic dyes. J Hazard Mater 192: 786-793. https://doi.org/10.1016/j.jhazmat.2011.05.084

Halbus AF, Horozov TS, Paunov VN (2019) Self-grafting copper oxide nanoparticles show a strong enhancement of their anti-algal and anti-yeast action. NANOSCALE Adv 1:2323-2336. https://doi. org/10.1039/c9na00099b
Halbus AF, Horozov TS, Paunov VN (2020) Surface-modified zinc oxide nanoparticles for antialgal and antiyeast applications. ACS Appl NANO Mater 3:440-451. https://doi.org/10.1021/acsanm.9b02045

Halliwell B, Gutteridge JMC (2015) Oxidative stress and redox regulation: adaptation, damage, repair, senescence, and death. In: Free radicals in biology and medicine, 5th edn. Oxford University Press, pp 199-283

Hartmann NB, der Kammer F, Hofmann T, Baalousha M, Ottofuelling S, Baun A (2010) Algal testing of titanium dioxide nanoparticlestesting considerations, inhibitory effects and modification of cadmium bioavailability. Toxicology 269:190-197. https://doi.org/10. 1016/j.tox.2009.08.008

Hartung T, Rovida C (2009) Chemical regulators have overreached. Nature 460:1080-1081. https://doi.org/10.1038/4601080a

He H, Zou Z, Wang B, Xu G, Chen C, Qin X, Yu C, Zhang J (2020) Copper oxide nanoparticles induce oxidative DNA damage and cell death via copper ion-mediated p38 MAPK activation in vascular endothelial cells. Int J Nanomedicine 15:3291-3302. https://doi. org/10.2147/IJN.S241157

Heinlaan M, Ivask A, Blinova I, Dubourguier H-C, Kahru A (2008) Toxicity of nanosized and bulk $\mathrm{ZnO}, \mathrm{CuO}$ and $\mathrm{TiO}_{2}$ to bacteria Vibrio fischeri and crustaceans Daphnia magna and Thamnocephalus platyurus. Chemosphere 71:1308-1316. https:// doi.org/10.1016/j.chemosphere.2007.11.047

Herrero E, Ros J, Belli G, Cabiscol E (2008) Redox control and oxidative stress in yeast cells. Biochim Biophys Acta-Gen Subj 1780:12171235. https://doi.org/10.1016/j.bbagen.2007.12.004

Howe DG, Blake JA, Bradford YM, Bult CJ, Calvi BR, Enge SR, Kadin JA, Kaufman TC, Kishores R, Laulederkind SF, Lewis SE, Moxon SAT, Richardson JE, Smith C (2018) Model organism data evolving in support of translational medicine. Lab Anim (NY) 47:277-289. https://doi.org/10.1038/s41684-018-0150-4

Hughes MN, Poole RK (1991) Metal speciation and microbial growth: the hard (and soft) facts. J Gen Microbiol 137:725-734. https://doi. org/10.1099/00221287-137-4-725

Ivask A, Juganson K, Bondarenko O, Mortimer M, Aruoja V, Kasemets K, Blinova I, Heinlaan M, Slaveykova V, Kahru A (2014) Mechanisms of toxic action of $\mathrm{Ag}, \mathrm{ZnO}$ and $\mathrm{CuO}$ nanoparticles to selected ecotoxicological test organisms and mammalian cells in vitro: a comparative review. Nanotoxicology 8:57-71. https:// doi.org/10.3109/17435390.2013.855831

Jamieson DJ (1998) Oxidative stress responses of the yeast Saccharomyces cerevisiae. YEAST 14:1511-1527.

Ji J, Long Z, Lin D (2011) Toxicity of oxide nanoparticles to the green algae Chlorella sp. Chem Eng J 170:525-530. https://doi.org/10. 1016/j.cej.2010.11.026

Jo HJ, Choi JW, Lee SH, Hong SW (2012) Acute toxicity of Ag and CuO nanoparticle suspensions against Daphnia magna: the importance of their dissolved fraction varying with preparation methods. J Hazard Mater 227:301-308. https://doi.org/10.1016/j.jhazmat.2012.05.066

Juganson K, Ivask A, Blinova I, Mortimer M, Kahru A (2015) NanoETox: new and in-depth database concerning ecotoxicity of nanomaterials. BEILSTEIN J Nanotechnol 6:1788-1804. https:// doi.org/10.3762/bjnano.6.183

Karlsson HL, Cronholm P, Gustafsson J, Moeller L (2008) Copper oxide nanoparticles are highly toxic: a comparison between metal oxide nanoparticles and carbon nanotubes. Chem Res Toxicol 21:17261732. https://doi.org/10.1021/tx800064j

Kasemets K, Ivask A, Dubourguier H-C, Kahru A (2009) Toxicity of nanoparticles of $\mathrm{ZnO}, \mathrm{CuO}$ and $\mathrm{TiO}_{2}$ to yeast Saccharomyces cerevisiae. Toxicol Vitr 23:1116-1122. https://doi.org/10.1016/j. tiv.2009.05.015

Kasemets K, Suppi S, Kuennis-Beres K, Kahru A (2013) Toxicity of $\mathrm{CuO}$ nanoparticles to yeast Saccharomyces cerevisiae BY4741 wild-type and its nine isogenic single-gene deletion mutants. Chem Res Toxicol 26:356-367. https://doi.org/10.1021/tx300467d 
Keerthana S, Kumar A (2020) Potential risks and benefits of zinc oxide nanoparticles: a systematic review. Crit Rev Toxicol 50:47-71. https://doi.org/10.1080/10408444.2020.1726282

Keller AA, McFerran S, Lazareva A, Suh S (2013) Global life cycle releases of engineered nanomaterials. J Nanoparticle Res:15. https://doi.org/10.1007/s11051-013-1692-4

Kharazian B, Hadipour NL, Ejtehadi MR (2016) Understanding the nanoparticle-protein corona complexes using computational and experimental methods. Int J Biochem Cell Biol 75:162-174. https:// doi.org/10.1016/j.biocel.2016.02.008

Klaine SJ, Edgington A, Seda B (2013) Nanomaterials in the environment. In: Férard J-F, Blaise C (eds) Encyclopedia of aquatic ecotoxicology. Springer Science, Dordrecht, pp 767-779

Klaper RD (2020) The known and unknown about the environmental safety of nanomaterials in commerce. Small 2000690:2000690. https://doi.org/10.1002/smll.202000690

Koerich JS, Nogueira DJ, Vaz VP, Simioni C, Da Silva MLN, Ouriques LC, Vicentini DS, Matias WG (2020) Toxicity of binary mixtures of $\mathrm{Al}_{2} \mathrm{O}_{3}$ and $\mathrm{ZnO}$ nanoparticles toward fibroblast and bronchial epithelium cells. J Toxicol Environ Heal A-CURRENT ISSUES 83: 363-377. https://doi.org/10.1080/15287394.2020.1761496

Kumar A, Pandey AK, Singh SS, Shanker R, Dhawan A (2011) Engineered $\mathrm{ZnO}$ and $\mathrm{TiO}_{2}$ nanoparticles induce oxidative stress and DNA damage leading to reduced viability of Escherichia coli. Free Radic Biol Med 51:1872-1881. https://doi.org/10.1016/j. freeradbiomed.2011.08.025

Laurent S, Boutry S, Muller RN (2018) Metal oxide particles and their prospects for applications. In: Mahmoudi M, Laurent S (eds) Iron oxide nanoparticles for biomedical applications. Elsevier, pp 3-42

Lead JR, Batley GE, Alvarez PJJ, Croteau M-N, Handy RD, McLaughlin MJ, Judy JD, Schirmer K (2018) Nanomaterials in the environment: behavior, fate, bioavailability, and effects-an updated review. Environ Toxicol Chem 37:2029-2063. https://doi.org/10.1002/etc. 4147

Lee W-M, An Y-J (2013) Effects of zinc oxide and titanium dioxide nanoparticles on green algae under visible, UVA, and UVB irradiations: no evidence of enhanced algal toxicity under UV pre-irradiation. Chemosphere 91:536-544. https://doi.org/10.1016/j. chemosphere.2012.12.033

Lesser MP (2006) Oxidative stress in marine environments: biochemistry and physiological ecology. Annu Rev Physiol 68:253-278. https:// doi.org/10.1146/annurev.physiol.68.040104.110001

Li M, Zhu L, Lin D (2011) Toxicity of ZnO nanoparticles to Escherichia coli: mechanism and the influence of medium components. Environ Sci Technol 45:1977-1983. https://doi.org/10.1021/es102624t

Li F, Liang Z, Zheng X, Zhao W, Wu M, Wang Z (2015) Toxicity of nano- $\mathrm{TiO}_{2}$ on algae and the site of reactive oxygen species production. Aquat Toxicol 158:1-13. https://doi.org/10.1016/j.aquatox. 2014.10.014

Libralato G, Galdiero E, Falanga A, Carotenuto R, de Alteriis E, Guida M (2017) Toxicity effects of ufnctionalized quantum dots, gold and polystyrene nanoparticles on target aquatic biological models: a erview. MOLECULES 22. https://doi.org/10.3390/ molecules22091439

Lin D, Ji J, Long Z, Yang K, Wu F (2012) The influence of dissolved and surface-bound humic acid on the toxicity of $\mathrm{TiO}_{2}$ nanoparticles to Chlorella sp. WATER Res 46:4477-4487. https://doi.org/10.1016/ j.watres.2012.05.035

Liu Z, Zhang M, Han X, Xu H, Zhang B, Yu Q, Li M (2016) $\mathrm{TiO}_{2}$ nanoparticles cause cell damage independent of apoptosis and autophagy by impairing the ROS-scavenging system in Pichia pastoris. Chem Biol Interact 252:9-18. https://doi.org/10.1016/j. cbi.2016.03.029

Lombi E, Donner E, Dusinska M, Wickson F (2019) A one health approach to managing the applications and implications of nanotechnologies in agriculture. Nat Nanotechnol 14:523-531. https://doi.org/10.1038/s41565-019-0460-8

Lu S, Zhang W, Zhang R, Liu P, Wang Q, Shang Y, Wu M, Donaldson K, Wang Q (2015) Comparison of cellular toxicity caused by ambient ultrafine particles and engineered metal oxide nanoparticles. Part Fibre Toxicol 12. https://doi.org/10.1186/s12989-015-0082-8

Malina C, Larsson C, Nielsen J (2018) Yeast mitochondria: an overview of mitochondrial biology and the potential of mitochondrial systems biology. FEMS Yeast Res 18. https://doi.org/10.1093/femsyr/ foy 040

Manier N, Bado-Nilles A, Delalain P, Aguerre-Chariol O, Pandard P (2013) Ecotoxicity of non-aged and aged $\mathrm{CeO}_{2}$ nanomaterials towards freshwater microalgae. Environ Pollut 180:63-70. https://doi. org/10.1016/j.envpol.2013.04.040

Márquez IG, Ghiyasvand M, Massarsky A, Babu M, Samanfar B, Omidi K, Moon TW, Smith ML, Golshani A (2018) Zinc oxide and silver nanoparticles toxicity in the baker's yeast, Saccharomyces cerevisiae. PLoS One 13:e0193111. https://doi.org/10.1371/ journal.pone.0193111

Mashock MJ, Kappell AD, Hallaj N, Hristova KR (2016) Copper oxide nanoparticles inhibit the metabolic activity of Saccharomyces cerevisiae. Environ Toxicol Chem 35:134-143. https://doi.org/10. 1002/etc.3159

Meyer JS, Lyons-Darden T, Garman ER, Middleton ET, Schlekat CE (2020) Toxicity of nanoparticulate nickel to aquatic organisms: review and recommendations for improvement of toxicity tests. Environ Toxicol Chem. https://doi.org/10.1002/etc.4812

Miller RJ, Lenihan HS, Muller EB, Tseng N, Hanna SK, Keller AA (2010) Impacts of metal oxide nanoparticles on marine phytoplankton. Environ Sci Technol 44:7329-7334. https://doi.org/10.1021/ es $100247 \mathrm{x}$

Minetto D, Ghirardini AV, Libralato G (2016) Saltwater ecotoxicology of $\mathrm{Ag}, \mathrm{Au}, \mathrm{CuO}, \mathrm{TiO}_{2}, \mathrm{ZnO}$ and $\mathrm{C}-60$ engineered nanoparticles: an overview. Environ Int 92-93:189-201. https://doi.org/10.1016/j. envint.2016.03.041

Mohammadinejad R, Moosavi MA, Tavakol S, Vardar DO, Hosseini A, Rahmati M, Dini L, Hussain S, Mandegary A, Klionsky DJ (2019) Necrotic, apoptotic and autophagic cell fates triggered by nanoparticles. Autophagy 15:4-33. https://doi.org/10.1080/15548627.2018. 1509171

Mordor Intelegence (2020) Metal oxide nanoparticles market - growth, trends, and forecast (2020 - 2025). https://www.mordorintelligence. com/industry-reports/metal-oxide-nanoparticles-market. Accessed 19 May 2020

Moriyama A, Takahashi U, Mizuno Y, Takahashi J, Horie M, Iwahashi H (2019) The truth of toxicity caused by yttrium oxide nanoparticles to yeast Cells. J Nanosci Nanotechnol 19:5418-5425. https://doi.org/ 10.1166/jnn.2019.16544

Mortezaee K, Najafi M, Samadian H, Barabadi H, Azarnezhad A, Ahmadi A (2019) Redox interactions and genotoxicity of metalbased nanoparticles: a comprehensive review. Chem Biol Interact 312:312. https://doi.org/10.1016/j.cbi.2019.108814

Naeemi AS, Elmi F, Vaezi G, Ghorbankhah M (2020) Copper oxide nanoparticles induce oxidative stress mediated apoptosis in carp (Cyprinus carpio) larva. GENE REPORTS 19. https://doi.org/10. 1016/j.genrep.2020.100676

Naseer B, Srivastava G, Qadri OS, Faridi SA, Islam RU, Younis K (2018) Importance and health hazards of nanoparticles used in the food industry. Nanotechnol Rev 7:623-641. https://doi.org/10.1515/ ntrev-2018-0076

Navarro E, Baun A, Behra R, Hartmann NB, Filser J, Miao A-J, Quigg A, Santschi PH, Sigg L (2008) Environmental behavior and ecotoxicity of engineered nanoparticles to algae, plants, and fungi. ECOTOXICOLOGY 17:372-386. https://doi.org/10.1007/s10646008-0214-0 
nee Rohder LA, Brandt T, Sigg L, Behra R (2018) Uptake and effects of cerium(III) and cerium oxide nanoparticles to Chlamydomonas reinhardtii. Aquat Toxicol 197:41-46. https://doi.org/10.1016/j. aquatox.2018.02.004

Nel A, Xia T, Madler L, Li N (2006) Toxic potential of materials at the nanolevel. Science 311:622-627. https://doi.org/10.1126/science. 1114397

Ng CT, Yong LQ, Hande MP, Ong CN, Yu LE, Bay BH, Baeg GH (2017) Zinc oxide nanoparticles exhibit cytotoxicity and genotoxicity through oxidative stress responses in human lung fibroblasts and Drosophila melanogaster. Int J Nanomedicine 12: 1621-1637. https://doi.org/10.2147/IJN.S124403

Nguyen VH, Lee B-J (2017) Protein corona: a new approach for nanomedicine design. Int J Nanomedicine 12:3137-3151. https:// doi.org/10.2147/IJN.S129300

Nguyen MK, Moon J-Y, Lee Y-C (2020) Microalgal ecotoxicity of nanoparticles: an updated review. Ecotoxicol Environ Saf:201. https:// doi.org/10.1016/j.ecoenv.2020.110781

NPD - Nanotechnology Products Database (2020) Introduction. https:// product.statnano.com/. Accessed 7 Aug 2020

Oh N, Park J-H (2014) Endocytosis and exocytosis of nanoparticles in mammalian cells. Int J Nanomedicine 9:51-63. https://doi.org/10. 2147/IJN.S26592

Otero-Gonzalez L, Garcia-Saucedo C, Field JA, Sierra-Alvarez R (2013) Toxicity of $\mathrm{TiO}_{2}, \mathrm{ZrO}_{2}, \mathrm{Fe}-0, \mathrm{Fe}_{2} \mathrm{O}_{3}$, and $\mathrm{Mn}_{2} \mathrm{O}_{3}$ nanoparticles to the yeast, Saccharomyces cerevisiae. Chemosphere 93:1201-1206. https://doi.org/10.1016/j.chemosphere.2013.06.075

Oukarroum A, Zaidi W, Samadani M, Dewez D (2017) Toxicity of nickel oxide nanoparticles on a freshwater green algal strain of Chlorella vulgaris. Biomed Res Int 2017:1-8. https://doi.org/10.1155/2017/ 9528180

Park E-J, Choi J, Park Y-K, Park K (2008) Oxidative stress induced by cerium oxide nanoparticles in cultured BEAS-2B cells. Toxicology 245:90-100. https://doi.org/10.1016/j.tox.2007.12.022

Paunovic J, Vucevic D, Radosavljevic T, Mandic-Rajcevic S, Pantic I (2020) Iron-based nanoparticles and their potential toxicity: focus on oxidative stress and apoptosis. Chem Biol Interact:316. https://doi. org/10.1016/j.cbi.2019.108935

Pereira RD, Geibel J (1999) Direct observation of oxidative stress on the cell wall of Saccharomyces cerevisiae strains with atomic force microscopy. Mol Cell Biochem 201:17-24. https://doi.org/10. 1023/A:1007007704657

Pulido-Reyes G, Rodea-Palomares I, Das S, Sakthivel TS, Leganes F, Rosal R, Seal S, Fernandez-Pinas F (2015) Untangling the biological effects of cerium oxide nanoparticles: the role of surface valence states. Sci Rep 5. https://doi.org/10.1038/srep15613

Pulido-Reyes G, Leganes F, Fernandez-Pinas F, Rosal R (2017) Bio-nano interface and environment: a critical review. Environ Toxicol Chem 36:3181-3193. https://doi.org/10.1002/etc.3924

Qian Y, Qin C, Chen M, Lin S (2020) Nanotechnology in soil remediation-applications vs. implications. Ecotoxicol Environ Saf 201. https://doi.org/10.1016/j.ecoenv.2020.110815

Quigg A, Chin W-C, Chen C-S, Zhang S, Jiang Y, Miao A-J, Schwehr KA, Xu C, Santschi PH (2013) Direct and indirect toxic effects of engineered nanoparticles on algae: role of natural organic matter. ACS Sustain Chem Eng 1:686-702. https://doi.org/10.1021/ sc400103x

Rajiv S, Jerobin J, Saranya V, Nainawat M, Sharma A, Makwana P, Gayathri C, Bharath L, Singh M, Kumar M, Mukherjee A, Chandrasekaran N (2016) Comparative cytotoxicity and genotoxicity of cobalt (II, III) oxide, iron (III) oxide, silicon dioxide, and aluminum oxide nanoparticles on human lymphocytes in vitro.
Hum Exp Toxicol 35:170-183. https://doi.org/10.1177/ 0960327115579208

Richter C, Park JW, Ames BN (1988) Normal oxidative damage to mitochondrial and nuclear-DNA is extensive. Proc Natl Acad Sci U S A 85:6465-6467. https://doi.org/10.1073/pnas.85.17.6465

Rodea-Palomares I, Boltes K, Fernandez-Pinas F, Leganes F, GarciaCalvo E, Santiago J, Rosal R (2011) Physicochemical characterization and ecotoxicological assessment of $\mathrm{CeO}_{2}$ nanoparticles using two aquatic microorganisms. Toxicol Sci 119:135-145. https://doi. org/10.1093/toxsci/kfq311

Rodea-Palomares I, Gonzalo S, Santiago-Morales J, Leganes F, GarciaCalvo E, Rosal R, Fernandez-Pinas F (2012) An insight into the mechanisms of nanoceria toxicity in aquatic photosynthetic organisms. Aquat Toxicol 122:133-143. https://doi.org/10.1016/j. aquatox.2012.06.005

Rogers NJ, Franklin NM, Apte SC, Batley GE, Angel BM, Lead JR, Baalousha M (2010) Physico-chemical behaviour and algal toxicity of nanoparticulate $\mathrm{CeO}_{2}$ in freshwater. Environ Chem 7:50-60. https://doi.org/10.1071/EN09123

Roma J, Matos AR, Vinagre C, Duarte B (2020) Engineered metal nanoparticles in the marine environment: a review of the effects on marine fauna. Mar Environ Res:161. https://doi.org/10.1016/j. marenveres.2020.105110

Sadiq IM, Pakrashi S, Chandrasekaran N, Mukherjee A (2011) Studies on toxicity of aluminum oxide $\left(\mathrm{Al}_{2} \mathrm{O}_{3}\right)$ nanoparticles to microalgae species: Scenedesmus sp and Chlorella sp. J Nanoparticle Res 13: 3287-3299. https://doi.org/10.1007/s11051-011-0243-0

Schiavo S, Oliviero M, Miglietta M, Rametta G, Manzo S (2016) Genotoxic and cytotoxic effects of $\mathrm{ZnO}$ nanoparticles for Dunaliella tertiolecta and comparison with $\mathrm{SiO}_{2}$ and $\mathrm{TiO}_{2}$ effects at population growth inhibition levels. Sci Total Environ 550:619 627. https://doi.org/10.1016/j.scitotenv.2016.01.135

Sendra M, Blasco J, Araujo CVM (2018) Is the cell wall of marine phytoplankton a protective barrier or a nanoparticle interaction site? Toxicological responses of Chlorella autotrophica and Dunaliella salina to $\mathrm{Ag}$ and $\mathrm{CeO}_{2}$ nanoparticles. Ecol Indic 95:1053-1067. https://doi.org/10.1016/j.ecolind.2017.08.050

Servin A, Elmer W, Mukherjee A, la Torre-Roche R, Hamdi H, White JC, Bindraban P, Dimkpa C (2015) A review of the use of engineered nanomaterials to suppress plant disease and enhance crop yield. J NANOPARTICLE Res 17. https://doi.org/10.1007/s11051-0152907-7

Sharan A, Nara S (2020) Exposure of synthesized $\mathrm{Co}_{3} \mathrm{O}_{4}$ nanoparticles to Chlorella minutissima: an ecotoxic evaluation in freshwater microalgae. Aquat Toxicol 224. https://doi.org/10.1016/j.aquatox. 2020.105498

Siddiqui MA, Ahamed M, Ahmad J, Khan MAM, Musarrat J, AlKhedhairy AA, Alrokayan SA (2012) Nickel oxide nanoparticles induce cytotoxicity, oxidative stress and apoptosis in cultured human cells that is abrogated by the dietary antioxidant curcumin. FOOD Chem Toxicol 50:641-647. https://doi.org/10.1016/j.fct. 2012.01.017

Siddiqui MA, Alhadlaq HA, Ahmad J, Al-Khedhairy AA, Musarrat J, Ahamed M (2013) Copper oxide nanoparticles induced mitochondria mediated apoptosis in human hepatocarcinoma cells. PLoS One 8:8. https://doi.org/10.1371/journal.pone.0069534

Sousa CA, Soares HMVM, Soares EV (2018a) Nickel oxide (NiO) nanoparticles disturb physiology and induce cell death in the yeast Saccharomyces cerevisiae. Appl Microbiol Biotechnol 102:28272838. https://doi.org/10.1007/s00253-018-8802-2

Sousa CA, Soares HMVM, Soares EV (2018b) Toxic effects of nickel oxide (NiO) nanoparticles on the freshwater alga 
Pseudokirchneriella subcapitata. Aquat Toxicol 204:80-90. https:// doi.org/10.1016/j.aquatox.2018.08.022

Sousa CA, Soares HMVM, Soares EV (2018c) Nickel Oxide (NiO) nanoparticles induce loss of cell viability in yeast mediated by oxidative stress. Chem Res Toxicol 31:658-665. https://doi.org/10.1021/acs. chemrestox.8b00022

Sousa CA, Soares HMVM, Soares EV (2019a) Metal(loid) oxide $\left(\mathrm{Al}_{2} \mathrm{O}_{3}\right.$, $\mathrm{Mn}_{3} \mathrm{O}_{4}, \mathrm{SiO}_{2}$ and $\mathrm{SnO}_{2}$ ) nanoparticles cause cytotoxicity in yeast via intracellular generation of reactive oxygen species. Appl Microbiol Biotechnol 103:6257-6269. https://doi.org/10.1007/ s00253-019-09903-y

Sousa CA, Soares HMVM, Soares EV (2019b) Chronic exposure of the freshwater alga Pseudokirchneriella subcapitata to five oxide nanoparticles: hazard assessment and cytotoxicity mechanisms. Aquat Toxicol 214:105265. https://doi.org/10.1016/j.aquatox.2019. 105265

Sousa CA, Soares HMVM, Soares EV (2019c) Nickel oxide nanoparticles trigger caspase- and mitochondria-dependent apoptosis in the yeast Saccharomyces cerevisiae. Chem Res Toxicol 32:245-254. https://doi.org/10.1021/acs.chemrestox.8b00265

Spurgeon DJ, Lahive E, Schultz CL (2020) Nanomaterial transformations in the environment: effects of changing exposure forms on bioaccumulation and toxicity. SMALL 16:2000618. https://doi.org/10. 1002/smll.202000618

Subramaniam VD, Murugesan R, Pathak S (2020) Assessment of the cytotoxicity of cerium, tin, aluminum, and zinc oxide nanoparticles on human cells. J NANOPARTICLE Res 22. https://doi.org/10. 1007/s11051-020-05102-3

Suman TY, Rajasree SRR, Kirubagaran R (2015) Evaluation of zinc oxide nanoparticles toxicity on marine algae chlorella vulgaris through flow cytometric, cytotoxicity and oxidative stress analysis. Ecotoxicol Environ Saf 113:23-30. https://doi.org/10.1016/j. ecoenv.2014.11.015

Sun TY, Bornhoft NA, Hungerbuhler K, Nowack B (2016) Dynamic probabilistic modeling of environmental emissions of engineered nanomaterials. Environ Sci Technol 50:4701-4711. https://doi.org/ 10.1021/acs.est.5b05828

Suppi S, Kasemets K, Ivask A, Kuennis-Beres K, Sihtmaee M, Kurvet I, Aruoja V, Kahru A (2015) A novel method for comparison of biocidal properties of nanomaterials to bacteria, yeasts and algae. $\mathrm{J}$ Hazard Mater 286:75-84. https://doi.org/10.1016/j.jhazmat.2014. 12.027

Taylor NS, Merrifield R, Williams TD, Chipman JK, Lead JR, Viant MR (2016) Molecular toxicity of cerium oxide nanoparticles to the freshwater alga Chlamydomonas reinhardtii is associated with supraenvironmental exposure concentrations. Nanotoxicology 10:3241. https://doi.org/10.3109/17435390.2014.1002868

Usman M, Farooq M, Wakeel A, Nawaz A, Cheema SA, Rehman HU, Ashraf I, Sanaullah M (2020) Nanotechnology in agriculture: current status, challenges and future opportunities. Sci Total Environ 721:137778. https://doi.org/10.1016/j.scitotenv.2020.137778

Vale G, Mehennaoui K, Cambier S, Libralato G, Jomini S, Domingos RF (2016) Manufactured nanoparticles in the aquatic environmentbiochemical responses on freshwater organisms: a critical overview. Aquat Toxicol 170:162-174. https://doi.org/10.1016/j.aquatox. 2015.11.019

Vance ME, Kuiken T, Vejerano EP, McGinnis SP, Hochella MF Jr, Rejeski D, Hull MS (2015) Nanotechnology in the real world: redeveloping the nanomaterial consumer products inventory. BEILSTEIN J Nanotechnol 6:1769-1780. https://doi.org/10.3762/ bjnano.6.181

Vasco MS, Alves LC, Corregidor V, Correia D, Godinho CP, Sa-Correia I, Bettiol A, Watt F, Pinheiro T (2017) 3D map distribution of metallic nanoparticles in whole cells using $\mathrm{MeV}$ ion microscopy. $\mathrm{J}$ Microsc 267:227-236. https://doi.org/10.1111/jmi.12561

Vimercati L, Cavone D, Caputi A, De Maria L, Tria M, Prato E, Ferri GM (2020) Nanoparticles: an experimental study of zinc nanoparticles toxicity on marine crustaceans. General overview on the health implications in humans. Front Public Health 8. https://doi.org/10.3389/ fpubh.2020.00192

von Moos N, Slaveykova VI (2014) Oxidative stress induced by inorganic nanoparticles in bacteria and aquatic microalgae-state of the art and knowledge gaps. Nanotoxicology 8:605-630. https://doi.org/ 10.3109/17435390.2013.809810

von Moos N, Bowen P, Slaveykova VI (2014) Bioavailability of inorganic nanoparticles to planktonic bacteria and aquatic microalgae in freshwater. Environ Sci 1:214-232. https://doi.org/10.1039/ c3en $00054 \mathrm{k}$

von Moos N, Maillard L, Slaveykova VI (2015) Dynamics of sub-lethal effects of nano- $\mathrm{CuO}$ on the microalga Chlamydomonas reinhardtii during short-term exposure. Aquat Toxicol 161:267-275. https:// doi.org/10.1016/j.aquatox.2015.02.010

von Moos N, Koman VB, Santschi C, Martin OJF, Maurizi L, Jayaprakash A, Bowen P, Slaveykova VI (2016) Pro-oxidant effects of nano- $\mathrm{TiO}_{2}$ on Chlamydomonas reinhardtii during short-term exposure. RSC Adv 6:115271-115283. https://doi.org/10.1039/ c6ra16639c

Wang D, Lin Z, Wang T, Yao Z, Qin M, Zheng S, Lu W (2016) Where does the toxicity of metal oxide nanoparticles come from: the nanoparticles, the ions, or a combination of both? J Hazard Mater 308: 328-334. https://doi.org/10.1016/j.jhazmat.2016.01.066

Wiench K, Wohlleben W, Hisgen V, Radke K, Salinas E, Zok S, Landsiedel R (2009) Acute and chronic effects of nano- and nonnano-scale $\mathrm{TiO}_{2}$ and $\mathrm{ZnO}$ particles on mobility and reproduction of the freshwater invertebrate Daphnia magna. Chemosphere 76: 1356-1365. https://doi.org/10.1016/j.chemosphere.2009.06.025

Wu F, Seib M, Mauel S, Klinzing S, Hicks AL (2020) A citizen science approach estimating titanium dioxide released from personal care products. PLoS One:15. https://doi.org/10.1371/journal.pone. 0235988

Xia T, Kovochich M, Brant J, Hotze M, Sempf J, Oberley T, Sioutas C, Yeh JI, Wiesner MR, Nel AE (2006) Comparison of the abilities of ambient and manufactured nanoparticles to induce cellular toxicity according to an oxidative stress paradigm. NANO Lett 6:17941807. https://doi.org/10.1021/nl061025k

Xia T, Kovochich M, Liong M, Maedler L, Gilbert B, Shi H, Yeh JI, Zink JI, Nel AE (2008) Comparison of the mechanism of toxicity of zinc oxide and cerium oxide nanoparticles based on dissolution and oxidative stress properties. ACS Nano 2:2121-2134. https://doi.org/ $10.1021 / \mathrm{nn} 800511 \mathrm{k}$

Xia B, Chen B, Sun X, Qu K, Ma F, Du M (2015) Interaction of $\mathrm{TiO}_{2}$ nanoparticles with the marine microalga Nitzschia closterium: growth inhibition, oxidative stress and internalization. Sci Total Environ 508:525-533. https://doi.org/10.1016/j.scitotenv.2014.11. 066

Xu L, Xu M, Wang R, Yin Y, Lynch I, Liu S (2020) The crucial role of environmental coronas in determining the biological effects of engineered nanomaterials. SMALL 16. https://doi.org/10.1002/ smll.202003691

Yetisen AK, Qu H, Manbachi A, Butt H, Dokmeci MR, Hinestroza JP, Skorobogatiy M, Khademhosseini A, Yun SH (2016) Nanotechnology in textiles. ACS Nano 10:3042-3068. https://doi. org/10.1021/acsnano.5b08176

Y in E, Zhao Z, Chi Z, Zhang Z, Jiang R, Gao L, Cao J, Li X (2020) Effect of Chlamydomonas reinhardtii on the fate of $\mathrm{CuO}$ nanoparticles in 
aquatic environment. Chemosphere 247:125935. https://oi.org/10. 1016/j.chemosphere.2020.125935

Yu Q, Liu Z, Xu H, Zhang B, Zhang M, Li M (2015) $\mathrm{TiO}_{2}$ nanoparticles promote the production of unsaturated fatty acids (UFAs) fighting against oxidative stress in Pichia pastoris. RSC Adv 5:4103341040. https://doi.org/10.1039/c5ra02366a

Yu S, Liu J, Yin Y, Shen M (2018) Interactions between engineered nanoparticles and dissolved organic matter: a review on mechanisms and environmental effects. J Environ Sci 63:198-217. https://doi. org/10.1016/j.jes.2017.06.021

Zemke-White WL, Clements KD, Harris PJ (2000) Acid lysis of macroalgae by marine herbivorous fishes: effects of acid $\mathrm{pH}$ on cell wall porosity. J Exp Mar Bio Ecol 245:57-68. https://doi.org/10. 1016/S0022-0981(99)00151-3

Zhang H, Ji Z, Xia T, Meng H, Low-Kam C, Liu R, Pokhrel S, Lin S, Wang X, Liao Y-P, Wang M, Li L, Rallo R, Damoiseaux R, Telesca D, Maedler L, Cohen Y, Zink JI, Nel AE (2012) Use of metal oxide nanoparticle band gap to develop a predictive paradigm for oxidative stress and acute pulmonary inflammation. ACS Nano 6: 4349-4368. https://doi.org/10.1021/nn3010087

Zhang W, Bao S, Fang T (2016) The neglected nano-specific toxicity of $\mathrm{ZnO}$ nanoparticles in the yeast Saccharomyces cerevisiae. Sci Rep 6. https://doi.org/10.1038/srep24839

Zhao J, Lin M, Wang Z, Cao X, Xing B (2020) Engineered nanomaterials in the environment: are they safe? Crit Rev Environ Sci Technol. https://doi.org/10.1080/10643389.2020.1764279

Zorova LD, Popkov VA, Plotnikov EY, Silachev DN, Pevzner IB, Jankauskas SS, Babenko VA, Zorov SD, Balakireva AV, Juhaszova M, Sollott SJ, Zorov DB (2018) Mitochondrial membrane potential. Anal Biochem 552:50-59. https://doi.org/10.1016/ j.ab.2017.07.009

Publisher's note Springer Nature remains neutral with regard to jurisdictional claims in published maps and institutional affiliations. 